AUTARQUIA ASSOCIADA À UNIVERSIDADE DE SÃO PAULO

\title{
ATIVIDADE ANTIMICROBIANA DE CROTAMINA E CROTAMINA-SÍMILE PROVENIENTE DO VENENO DE SERPENTES DO GÊNERO Crotalus
}

\author{
Marcela Di Giacomo Messias
}

Dissertação apresentada como parte dos
requisitos para obtenção do Grau de
Mestre em Ciências na Área
de Tecnologia Nuclear-Aplicações

Orientador:

Prof. Dr. Patrick Jack Spencer 
INSTITUTO DE PESQUISAS ENERGÉTICAS E NUCLEARES

Autarquia associada à Universidade de São Paulo

\section{ATIVIDADE ANTIMICROBIANA DE CROTAMINA E CROTAMINA-SÍMILE PROVENIENTE DO VENENO DE SERPENTES DO GÊNERO Crotalus}

Marcela Di Giacomo Messias

Dissertação apresentada como parte dos requisitos para obtenção do Grau de Mestre em Ciências na Área de Tecnologia Nuclear - Aplicações

Orientador:

Prof. Dr. Patrick Jack Spencer

\#

São Paulo 


\section{Auxílio CNPq}

Autorizo a reprodução e divulgação total ou parcial deste trabalho, para fins de estudo e pesquisa, desde que citada a fonte.

MESSIAS, Marcela, D. G. Atividade antimicrobiana de crotamina e crotaminasímile proveniente do veneno de serpentes do gênero Crotalus. 2017. 56p. Dissertação (Mestrado em Tecnologia Nuclear) Instituto de Pesquisas Energéticas e Nucleares - IPEN-CNEN/SP. São Paulo. Disponível em: $<$ http://www.teses.usp.br>.

Ficha catalográfica elaborada pelo Sistema de geraçăo automática da Biblioteca IPEN/USP, com os dados fornecidos pelo(a) autor(a)

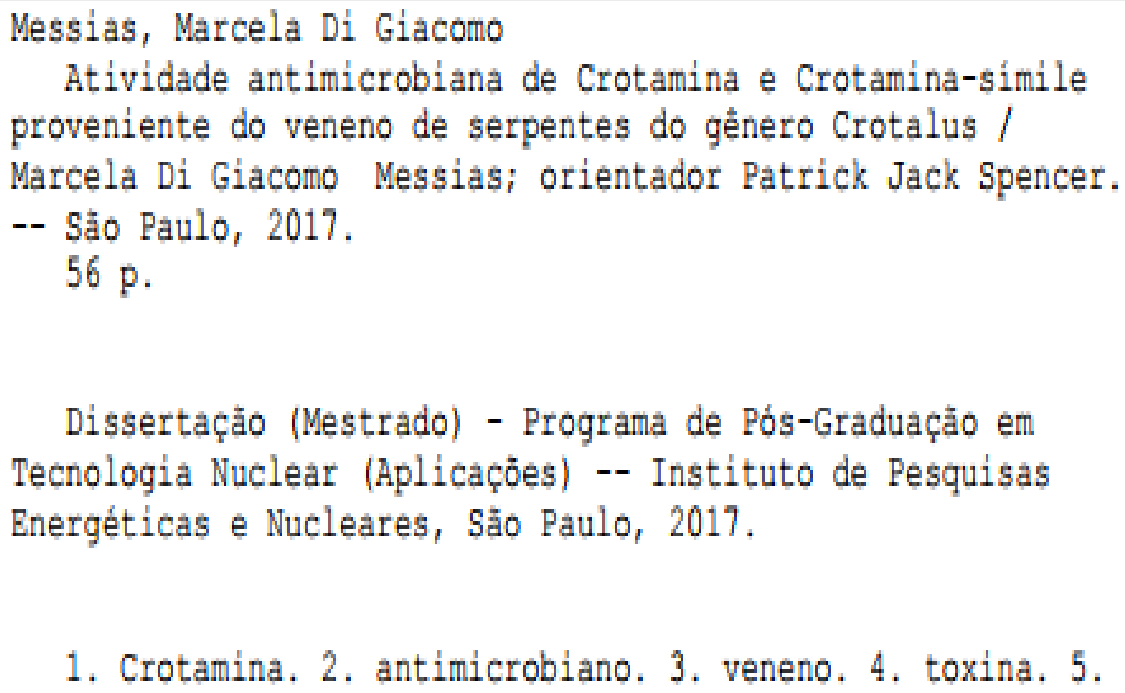

1. Crotamina. 2. antimicrobiano. 3. veneno. 4. toxina. 5. peptídeo. I. Spencer, Patrick Jack, orient. II. Título. 
Dedico este trabalho a minha família.

Pelo apoio e pelo amor de sempre.

Obrigada! 


\section{Agradecimentos}

Ao criador do universo, agradeço a oportunidade.

Ao meu orientador, Dr. Patrick Jack Spencer por acreditar e por me apoiar todas as vezes que precisei.

À Dra. Tamara Mieco Fucase, por toda ajuda e incentivo e por fazer parte tanto deste projeto, quanto da vida. Pelo passado, presente e futuro.

Ao meu amigo Podé (José Pedro Prezotto Neto) por todas as conversas, ajuda e amizade no decorrer destes anos.

Ao colega Samuel Levindo, por todo apoio, conversas e conselhos

A Mariana, Bruno, Paula, Ed, pelos momentos de descontração

A Evelyn Caroline e Felipe Douglas por todo apoio, amizade e conselhos

À Dra. Nancy Oguiura do Instituto Butantan pelo fornecimento dos anticorpos policlonais

Ao Dr. Claudio Fontes Sousa por fornecer a fração crotamina de C. d. r.

Ao Dr. Daniel Perez Vieira pelo auxílio fornecido para os ensaios de citotoxicidade e análise estatística.

À Glaucie Jussilane Alves, por todo auxílio durante o experimento in vivo

À Dra. Nanci do Nascimento (in memoriam) pela orientação, ajuda, incentivo em diversas etapas deste trabalho

Ao Dr. Daniel Pimenta e Me. Douglas Oscar Ceolin Mariano pelo suporte nas análises por espectrometria de massas

Ao João Ezequiel de Oliveira (Johnny), por ser a pessoa mais prestativa que conheço e por toda ajuda nas purificações

À Miriam Fussae pelo fornecimento de reagentes. 
À Dra. Olga Zazuco Higa pelo fornecimento de reagentes e por disponibilizar os laboratórios e equipamentos.

A Rute, Arlete, Neide, por sempre estarem dispostas a ajudar nas questões burocráticas e pelas conversas.

A aluna de iniciação científica Fernanda Mouro Galuzzi por todo auxílio sempre que precisei.

Ao IPEN pelo fornecimento de toda a estrutura necessária.

Ao Cnpq pelo financiamento do projeto 
“ Todos evoluem desidratando, seja pelo suor do trabalho ou pelas lágrimas do sofrimento." (Chico Xavier) 


\section{Atividade antimicrobiana de crotamina e crotamina-símile provenientes do veneno de serpentes do gênero Crotalus}

\section{Marcela Di Giacomo Messias \\ RESUMO}

Os venenos de serpentes são alvos de pesquisas constantes, pois possuem 90 a $95 \%$ do seu peso seco em proteínas que exercem diversas atividades fisiológicas em suas presas. As espécies do gênero Crotalus estudadas no presente trabalho possuem venenos capazes de induzir alterações neurotóxicas, miotóxicas e causam distúrbios de coagulação no caso do veneno de Crotalus vegrandis. A crotamina é um peptídeo catiônico proveniente do veneno de Crotalus durissus terrificus, com atividade miotóxica e antimicrobiana já descritas. $O$ trabalho avaliou a atividade antimicrobiana de crotamina e crotamina-símile provenientes do veneno de serpentes do gênero Crotalus. O veneno bruto foi fracionado por três diferentes métodos cromatográficos, e, para avaliar a técnica, utilizou-se SDS-PAGE. Na etapa de identificação e caracterização de crotamina, foi feito ELISA, utilizando como anticorpo primário uma IgG policlonal anti-crotamina. A fim de analisar a atividade antimicrobiana foram realizados os ensaios de difusão em gota e CIM (Concentração inibitória mínima). A citoxicidade em células murinas, foi avaliada por MTS. A purificação por duas etapas cromatográficas foi suficiente para observarmos a presença da crotamina e crotamina-símile puras (SDSPAGE). Foram identificados dois peptídeos promissores com relação à atividade antimicrobiana no veneno de $C$. vegrandis. Todas as amostras testadas foram imunorreativas. Os peptídeos apresentam atividade antimicrobiana com diferentes especificidades e potências. Não houve alta toxicidade frente à linhagem celular murina, apresentando-se como um futuro protofármaco.

Palavras-chave: crotamina; atividade antimicrobiana; Crotalus vegrandis; Crotalus durissus; crotamina-símile. 


\title{
Antimicrobial activity of crotamine and crotamine homologue from snake venom of Crotalus genus.
}

\section{Marcela Di Giacomo Messias}

\begin{abstract}
Snake venoms are common targets of research due to their high protein content (up to 90 to $95 \%$ of dry weight) which affect several biological functions. The species of the genus Crotalus that were studied in the present document have venoms able to induce neurotoxic, myotoxic and coagulation disorders (Crotalus vegrandis). Crotamine is a cationic polypeptide from the venom of rattlesnake Crotalus durissus terrificus, described as myotoxic and displaying antimicrobial activity. The present study aimed to evaluate the antimicrobial activity of crotamine and crotamine-like toxins from the genus Crotalus. Crude venom was fractionated by three different chromatographic methods, and to confirm the efficiency of purification SDS-PAGE was used. In the purification and characterization stage of crotamine, we performed ELISA, using as primary antibody a polyclonal anti-crotamine IgG. To analyze the antimicrobial activity, antibiograms (droplet diffusion) and MIC (minimal inhibitory concentration) assays were performed. Citotoxicity in murine cells was evaluated by MTS. The results of two chromatographic steps were enough to obtain isolated crotamine and crotamine-like (SDS-PAGE). Two promising peptides from $C$ vegrandis were identified for antimicrobial activity. Crude venom and crotamine-like fraction from $C$. $d$. ruruima were immunoreactive in ELISA assays. Peptides showed antimicrobial activity with different specificities and potencies. The toxicity towards murine cells was low, indicating the potential of these peptides as a model to future drug.
\end{abstract}

Key words: crotamine; antimicrobial activity; Crotalus vegrandis; Crotalus durissus; crotamine-like. 


\section{LISTA DE FIGURAS}

Figura 1 Exemplar de Crotalus durissus terrificus e Crotalus durissus 7 ruruima

Figura 2 Exemplar de Crotalus vegrandis 8

$\begin{array}{lll}\text { Figura } 3 & \text { Etrutura da Crotamina } & 9\end{array}$

Figura 4 Alinhamento e sequência da Crotamina e crotamina-símile 10 de C. d. r.

Figura 5 Imunorreatividade de venenos crotálicos 19

Figura 6 Fracionamento de C. d. t. em coluna de exclusão molecular 21

Figura 7 Gel SDS Page 15\% das frações coletadas durante a 22 cromatografia de exclusão molecular

Figura 8 Cromatografia de troca catiônica da fração 4

Figura 9 Gel SDS Page 15\% das frações obtidas durante troca 24 catiônica

Figura 10 Antibiograma realizado com crotamina em diferentes espécies

Figura 11 RP-HPLC fração crotamina $(90 \%$ ACN) 26

Figura 12 RP-HPLC fração crotamina (66\% ACN) 27

Figura 13 Gel SDS PAGE 15\% das frações de RP-HPLC 28

Figura 14 Camundongos Swiss com paralisia no trem posterior 30

Figura 15 Fracionamento de $C$. vegrandis em coluna de exclusão 31 molecular

Figura 16 Gel SDS Page 15\% das frações coletadas durante a 31 cromatografia de exclusão molecular

Figura 17 Cromatografia de troca catiônica da fração 7 C.v. 32

Figura 18 Gel SDS Page 15\% da fração coletada da troca catiônica 33

Figura 19 Antibiograma realizado com fração 6, 7, 8, 9 em diferentes 34 espécies 
Figura 20 Gel SDS Page $15 \%$ da fração C. d. r.

Figura 21 CIM realizado com crotamina (E. coli) 36

Figura 22 CIM realizado com crotamina (M. luteus) 37

Figura 24 CIM realizado com fração $6 \quad 38$

Figura 25 CIM realizado com crotamina C.d.r. 39

Figura 26 Gráfico de viabilidade celular 40 


\section{LISTA DE TABELAS}

Tabela 1

Biofármacos derivados de venenos de serpentes

4

Tabela 2

Avaliação da paralisia do trem posterior

29 


\section{LISTA DE ABREVIATURAS}

ACN - Acetonitrila

AMP - Antimicrobial peptide

Anti - Antibiótico (controle positivo)

ATCC - American Type Culture Collection

C.d.t. - Crotalus durissus terrificus

C.d.r. - Crotalus durissus ruruima

C.v. - Crotalus vegrandis

DMEM - Dulbecco's Modified Eagle's Medium

DMSO - Dimethyl sulfoxide

O. D. - Optical density

HOAc - Ácido acético glacial

$\mathrm{HCl}$ - Ácido clorídrico

HPLC - High Performance Liquid Chromatography

$\lg G$ - Imunoglobulina $G$

MTS - (3-(4,5-dimethylthiazol-2-yl)-5-(3-carboxymethoxyphenyl)-2-(4-

sulfophenyl)-2H-tetrazolium)

$\mathrm{NaCl}$ - Sodium chloride

NCBI - National Center for Biotechnology Information

PAGE - Polyacrylamide Gel Electrophoresis

PBS - Phosphate Buffer Saline

PBST - Phosphate Buffer Saline with Tween 20

PMS - Phenazine methosulfate

SDS - Sodium Dodecyl Sulphate

SFB - Soro Fetal Bovino

TEMED - N,N,N,N-tetrametil etilenodiamina

TFA - Trifluoroacetic acid

TBS - Tris Buffer Saline

TMB - 3,3-,5,5- Tetrametilbenzidina

TSB - Tryptic Soy Broth 


\section{Sumário}

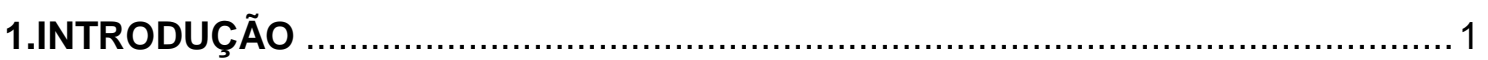

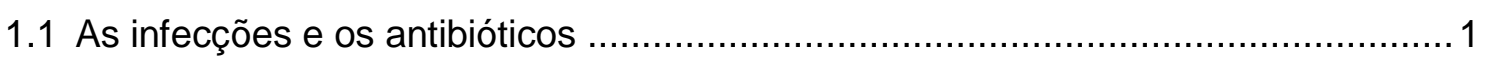

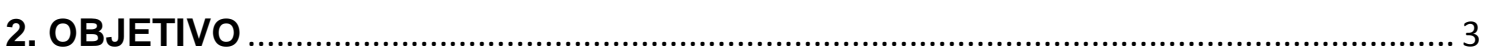

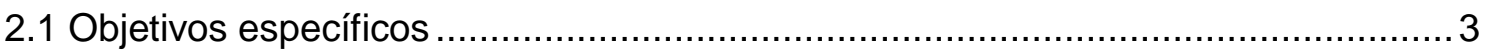

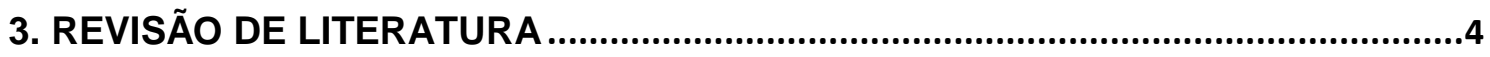

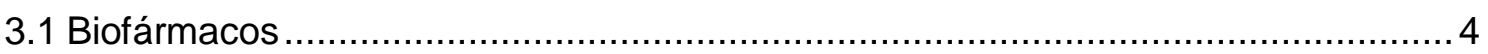

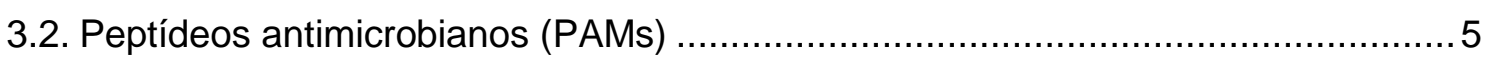

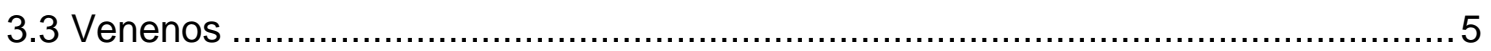

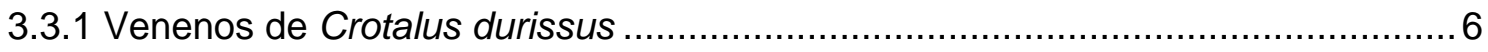

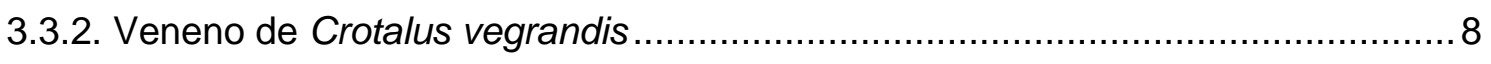

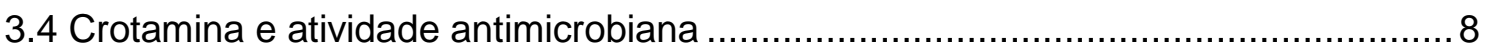

4. METODOLOGIA

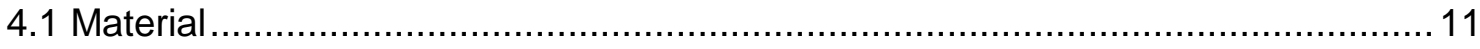

4.2 Anticorpos para Ensaios imunoenzimáticos ................................................ 11

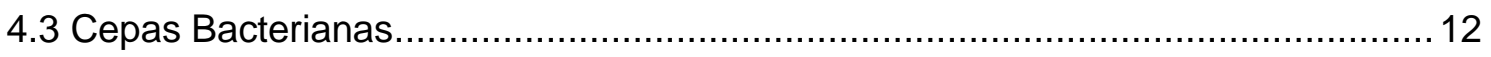

4.4.ELISA (Enzyme-linked imuno sorbent assay) para detecção de crotamina-símile 12

4.5. Fracionamento dos venenos crotálicos ......................................................... 13

4.5.1. Cromatografia de Exclusão molecular...................................................... 13

4.5.2 Cromatografia de Troca Catiônica............................................................ 13

4.5.3 Cromatografia de Fase Reversa ............................................................... 14

4.6 Eletroforese em gel da poliacrilamida (SDS-PAGE) ......................................... 14

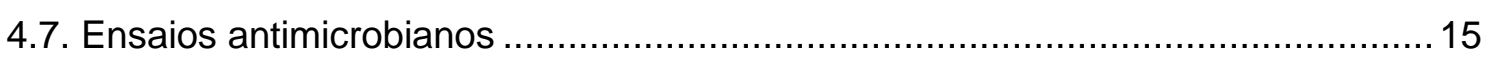

4.7.1 Antibiograma - Difusão em gota ...................................................... 15

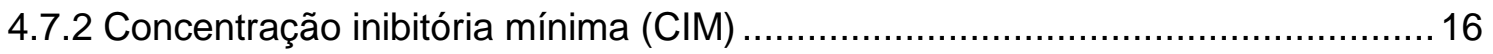

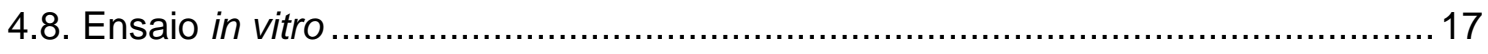

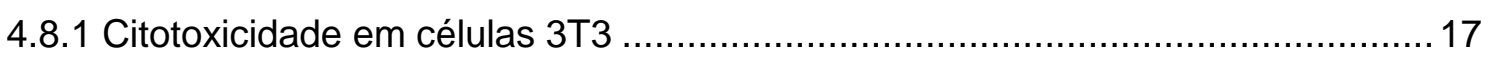

4.9. Ensaio in vivo de paralisia do trem posterior em camundongos Swiss................. 18

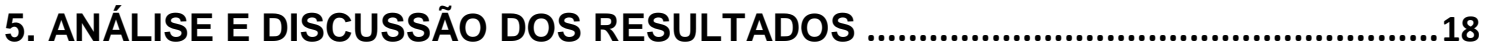


5.1 ELISA Indireto (Indirect Enzyme linked ImmunoSorbent Assay) ......................... 18

5.2 Purificação do veneno de Crotalus durissus terrificus ......................................20

5.2.1 Cromatografia Líquida - Exclusão molecular do veneno bruto de $C$. d. t. e SDSPAGE 15\% das frações coletadas da cromatografia............................................ 20

5.2.2 Cromatografia Líquida - Troca catiônica da fração 4 de C.d.t. e SDS-PAGE 15\%

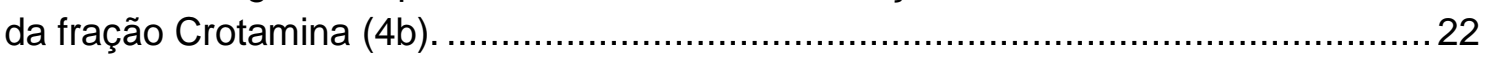

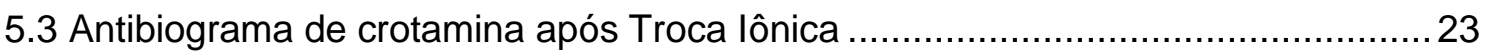

5.4 Análise de estabilidade da atividade miotóxica e antimicrobiana da crotamina .....24

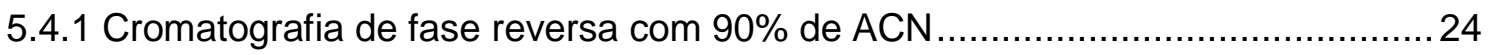

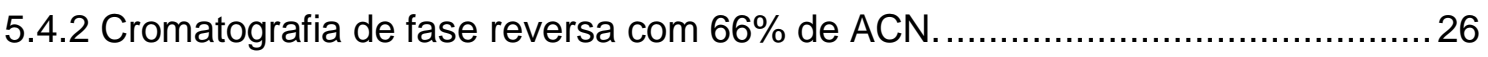

5.5 Ensaio in vivo de paralisia do trem posterior de camundongos Swiss..................27

5.6 Purificação do veneno de Crotalus vegrandis ...................................................2.

5.6.1 Exclusão molecular do veneno bruto de C. v. e SDS-PAGE das frações

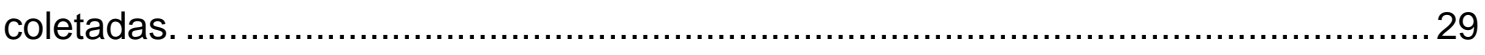

5.7 Antibiograma dos picos da exclusão molecular do veneno de $C$. $v$. testado em $M$.

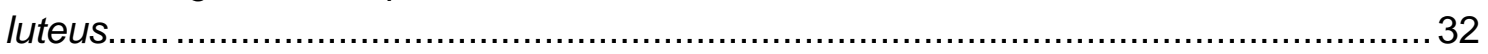

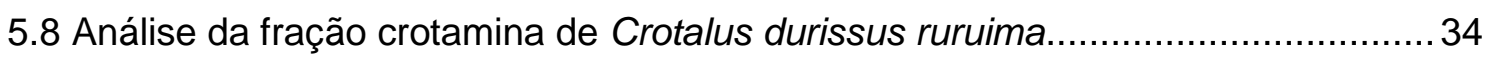

5.8.1 SDS-PAGE 15\% com fração crotamina de $C$. $d$. $r$............................................... 34

5.9 Análise comparativa da Concentração inibitória mínima (CIM) da crotamina e

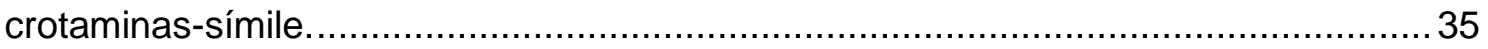

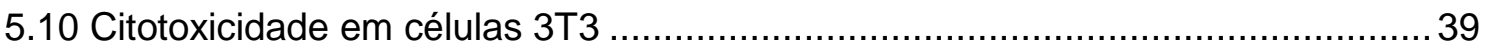

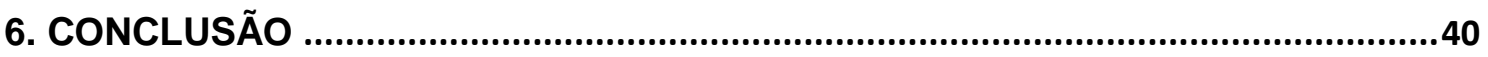

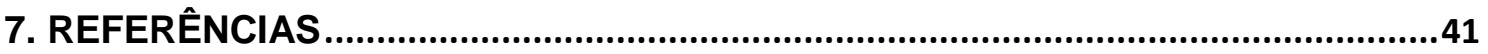




\section{INTRODUÇÃO}

\subsection{As infecções e os antibióticos}

As infecções bacterianas são conhecidas mundialmente por serem as principais causas de doenças ao longo dos séculos. Com a descoberta de Alexander Flemming, este problema tendeu a desaparecer e parou de ser visto como ameaçador. Porém, uma reviravolta logo após a criação do primeiro antibiótico, a Penicilina, mudou o curso do fim das infecções. Os primeiros indícios de resistência foram com a enzima penicilinase, hoje descrita como $\beta$ lactamase, conhecida por clivar os anéis beta-lactâmicos dos antibióticos, deixando a droga sem efeito (HAWKEY, 1988).

A resistência bacteriana se tornou um problema de saúde mundial pois tornou-se a quarta doença que mata no mundo (OMS, 2016). Tais resistências, são consideradas metabólicas e enzimáticas, que pode afetar não somente 0 tratamento de quem faz uso de antimicrobianos, mas também todo o ecossistema. Mais de $50 \%$ das prescrições de antibióticos são inapropriadas, e em diversos países, estes são utilizados sem prescrições médicas, fator que favorece o aumento da resistência (LEVY, 1994; SALYERS, 1997).

O uso incorreto de antibióticos ao longo dos anos favoreceu a criação de novos mecanismos de resistência, criando as chamadas "superbactérias". Estas cepas de micro-organismos crescem exponencialmente mesmo em concentrações altas de antibióticos, maiores que as dosagens terapêuticas utilizadas, portanto, existe a grande necessidade da pesquisa na busca de novas drogas a fim de sanar o problema (QUEIROZ, 2010).

Sabe-se que este mecanismo está presente em praticamente todas as espécies bacterianas, sendo estudado assiduamente desde o momento da aquisição da resistência até manifestações moleculares desta (JACOBY, 1991; JACOBY, 1998). 
A resistência microbiana pode estar associada a fenômenos genéticos, que podem ocorrer durante a reprodução bacteriana, resultando em cópias da sequência de bases defeituosas que formam o DNA cromossômico, responsáveis pelo código genético. Ou a resistência pode ter outra origem como a importação dos genes, consistindo na resistência transferível. Esta ocorre através dos mecanismos de transdução, transformação e conjugação, e frequentemente envolve genes situados em plasmídeos e transpósons (MARTINEZ, 2015).

Com o aumento de caso de resistência a cada ano, os cientistas começam a avaliar opções terapêuticas alternativas. Quando realizamos um balanço, a quantidade de mecanismos novos de resistência microbiana que surge é amplamente desproporcional a descoberta de novas drogas que consigam driblar estes mecanismos (MICHAEL et al., 2014; HOLMES, 2016).

A academia e a indústria farmacêutica têm empenhado grandes esforços no desenvolvimento de novos fármacos antimicrobianos, seja pela síntese de novos compostos, seja pela investigação de novas biomoléculas (TOKE, 2005). 


\section{OBJETIVO}

Avaliar a atividade antimicrobiana da crotamina e das crotaminas-símiles

\subsection{Objetivos específicos}

- Isolar e caracterizar a crotamina e crotamina-símile do veneno de Crotalus vegrandis

- Avaliar a atividade antimicrobiana da crotamina e das crotaminassímiles proveniente do veneno das serpentes Crotalus vegrandis e Crotalus durissus ruruima em bactérias Gram-positivas e Gram-negativas. 


\section{REVISÃO DE LITERATURA}

\subsection{Biofármacos}

Os biofármacos são medicamentos produzidos através de técnicas biotecnológicas que podem ser extraídos de órgãos, tecidos, micro-organismos e venenos animais. (CARREIRA et al., 2013).

Atualmente, sabe-se que os venenos de serpentes são explorados justamente por conterem substâncias promissoras para diferentes terapêuticas. Peptídeos hipotensores botrópicos deram origem ao Captopril, uma das drogas mais comuns para pacientes hipertensos (ROCHA \& SILVA, 1949).

O Reptilase ${ }^{\circledR}$ é um importante biofármaco derivado do veneno de Bothrops atrox. Trata-se de uma enzima trombina-símile que é capaz de detectar e quantificar fibrinogênio, ainda que os pacientes estejam em tratamento com uso de anticoagulantes, como heparina. Podemos citar também o Protac ${ }^{\circledR}$, que funciona como ativador da proteína $C$, para uso de pacientes com risco de trombose (BON, 1994).

Tabela 1: Biofármacos provenientes do veneno de serpentes.

\begin{tabular}{|l|l|l|}
\hline $\begin{array}{l}\text { FARMACO I } \\
\text { NOME COMERCIAL }\end{array}$ & ALVO E FUNÇAOO / TRATAMENTO & ESPÉCIE DE ORIGEM \\
\hline Captopril; enalapril & Inibidor da ECA / hipertensão & Bothrops jararaca \\
\hline Integrilin (eptifibatide) & $\begin{array}{l}\text { Inibição da agregaçăo plaquetária/ } \\
\text { sindrome aguda coronariana }\end{array}$ & Sisturus miliarus barbouri \\
\hline Aggrastat (tirofiban) & $\begin{array}{l}\text { Inibidor da GPIllb-llla I infarto do } \\
\text { miocárdio, isquemia refratária }\end{array}$ & Echis carinatus \\
\hline Ancrod (Viprinex) & Inibidor de fibrinogênio & Agkistrodon rhodostoma \\
\hline Defibrase & $\begin{array}{l}\text { Inibidor de trombina e protrombina / } \\
\text { infarto cerebral agudo, angina peitoral } \\
\text { inespecifica }\end{array}$ & Bothrops moojeni \\
\hline Hemocoagulase & $\begin{array}{l}\text { Efeito similar a trombina e atividade } \\
\text { tromboplastinica / prevenção e } \\
\text { tratamento de hemorragia }\end{array}$ & Bothrops atrox \\
\hline Protac / Ativador da Proteina C & $\begin{array}{l}\text { Ativador da proteina C / diagnóstico } \\
\text { clinico de distúrbios hemostáticos }\end{array}$ & $\begin{array}{l}\text { Agkistrodon } \\
\text { contortrix contortrix }\end{array}$ \\
\hline Reptilase & $\begin{array}{l}\text { Diagnóstico de desordens de de } \\
\text { coagulação sanguinea }\end{array}$ & Bothrops jararaca \\
\hline Ecarin & Ativador da protrombina / diagnóstico & Echis carinatus \\
\hline Exanta / ximelagatran & Anticoagulante, inibidor da trombina & Naja spp \\
\hline
\end{tabular}

Fonte: Donato, 2008. 


\subsection{Peptídeos antimicrobianos (PAMs)}

Os peptídeos antimicrobianos - PAMs (ou AMPs - antimicrobial peptides) são pequenas moléculas proteicas com propriedades catiônicas em $\mathrm{pH}$ neutro. Tais moléculas contém regiões hidrofóbicas importantes para sua conformação estrutural, resultando em uma estrutura anfipática, que possibilita a interação com a parede celular bacteriana e com a bicamada fosfolipídica da membrana celular. Podem ser constantemente expressos durante o ciclo de vida de organismos ou então a partir de estímulos gerados por invasões bacterianas, constituindo uma pré ou pós-barreira de defesa contra as mesmas (HANCOCK \& SAHL, 2006; BENKO-ISEPPON et al., 2010; ODINTSOVA \& EGOROV, 2012).

PAMs são componentes essenciais da imunidade inata encontrados amplamente em todos os organismos vivos, que variam desde seres unicelulares até vertebrados. Podem ser classificados como catalecidinas e defensinas, sendo esta última, objeto de estudo deste trabalho (BELARMINO \& BENKOISEPPON, 2010; ODINTSOVA \& EGOROV, 2012; KANG, et al, 2017).

Dentre estes animais, podemos destacar as serpentes, que em sua peçonha, rica em proteínas e peptídeos, podem apresentar moléculas com atividades antimicrobianas, como as $\beta$-defensinas ou a crotamina, proveniente da peçonha da serpente Crotalus durissus terrificus (OGUIURA; BONIMITAKE; RÁDIS-BAPTISTA, 2005).

\subsection{Venenos}

Os venenos de animais, em geral, têm finalidade de defesa e/ou predação, causando distúrbios fisiológicos em suas presas. Costumam ser compostos por toxinas complexas que no decorrer da evolução foram se aprimorando. Como estas toxinas afetam funções fisiológicas de suas presas, algumas vezes funções específicas, entende-se que possuem grande potencial para produção de novos fármacos. No decorrer dos anos, a quantidade de 
estudos e isolamentos destas toxinas vem crescendo, a fim de desenvolver novos fármacos com diversas finalidades (LEWIS e GARCIA, 2003) inclusive antibióticos.

Os venenos de serpentes costumam ser complexos, pois possuem atividades biológicas diversas. Cerca de 90 a 95\% do peso seco do veneno é constituído de proteínas e peptídeos (STOCKER, 1990). Nestes, estão inclusos enzimas, toxinas não enzimáticas e proteínas não tóxicas. Já a fração não proteica compreende cátions metálicos, carboidratos, nucleosídeos, aminas biogênicas e níveis menores de aminoácidos livres e lipídeos (CARDOSO, 2003). Dentre estes componentes, todos aqueles com ação fisiológica têm potencial uso farmacológico, seja como ferramenta, seja como protofármaco.

\subsubsection{Venenos de Crotalus durissus}

As cascavéis pertencem à família Viperidae, sub-família Crotalinae, gênero Crotalus. O gênero de serpentes Crotalus tem se destacado ao longo do tempo, pois há grande interesse na pesquisa de substâncias bioativas de seu veneno. Este gênero, no Brasil, é representado por uma única espécie, $C$. durissus, e classificada em subsespécies como, $C . d$. terrificus, $C . d$. collilineatus, $C . d$. cascavella, $C$. $d$. ruruima e C. d. marajoensis. Essas subespécies são distribuídas nas mais diversas regiões do Brasil (PINHO \& PEREIRA, 2001). 
Figura 1: Exemplar de Crotalus durissus terrificus (à esquerda); Crotalus durissus ruruima (à direita).

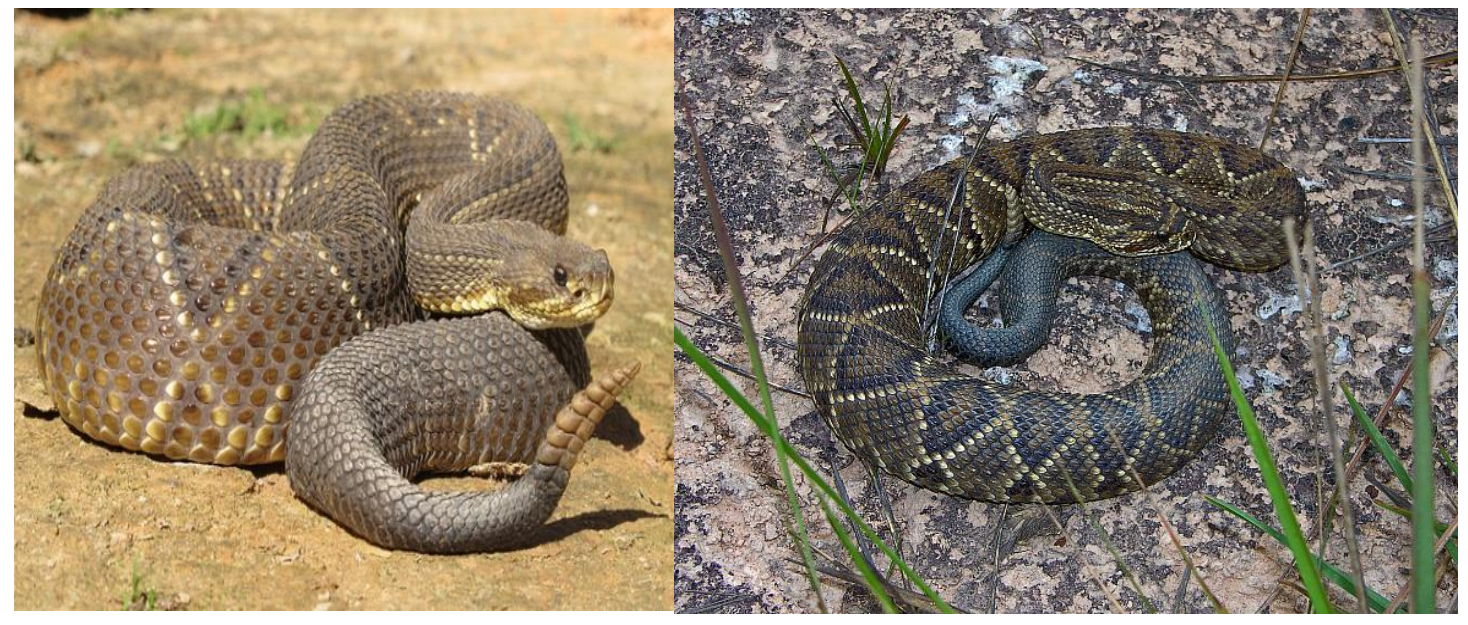

Fonte: à Esquerda (Pedro H. Martins - flickr) à direita (Hoge, 1965).

As cascavéis sul-americanas distribuem-se de maneira descontinua pelo Brasil, da mesma maneira que seus acidentes. Estas serpentes são responsáveis por $7,7 \%$ dos acidentes ofídicos registrados no país, sendo que estes podem representar até $30 \%$ dos acidentes em determinada região (BRASIL, 2001).

Sua peçonha apresenta-se como um complexo de toxinas e enzimas, onde são encontradas as toxinas convulxina, giroxina, crotoxina e crotamina e as enzimas fosfodiesterase, L-amino-oxidase e 5-nucleotidase (DU \& CLEMETSON 2002; RANGEL-SANTOS et al., 2004). Apresenta ainda uma mistura de peptidases, como crotalocitina, trombocitina (DE SOUZA SPINOSA, 2008).

O veneno de $C$. $d$. r. pode ser classificado em branco ou amarelo, de acordo com a sua aparência. Sendo o branco, descrito como coagulante, miotóxico, edematogênico e com propriedades hemolíticas, assemelha-se ao veneno de $C$. d. $t$. Já o veneno classificado como amarelo, possui atividade hemorrágica, necrótica, caseinolítica e presença de crotamina (DOS-SANTOS, 1993). 


\subsubsection{Veneno de Crotalus vegrandis}

O veneno de $C$. v., conhecida como Uracoan na Venezuela, tem ação neurotóxica, miotóxica e causa distúrbios da coagulação. A miotoxicidade leva a rabdomiólise, causando danos aos músculos esqueléticos. Em acidentes graves com esta espécie, o indivíduo pode ir a óbito por hemorragias locais e principalmente sistêmicas, embora possam ocorrer paradas respiratórias devido à alta neurotoxicidade e miotoxicidade (RODRIGUEZ-ACOSTA, 1995).

Figura 2: Exemplar de Crotalus vegrandis

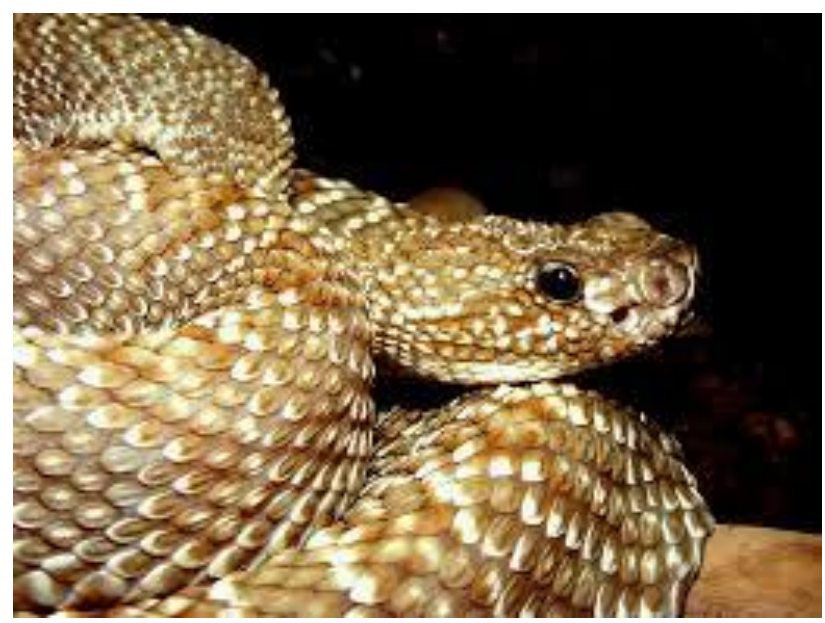

Fonte: Uniprot.

VIALA e colaboradores (2005) identificaram a presença de crotaminasímile por western blot na peçonha de C. v., fato este que motivou a realização deste trabalho. Além disso, desde 1988 é evidenciado propriedades miotóxicas na peçonha de C.v., o que reforça presença de crotamina-símile (BOBER, 1988).

\subsection{Crotamina e atividade antimicrobiana}

A Crotamina é um polipeptídeo catiônico proveniente do veneno da espécie sul-americana $C$. $d$. $t$. Foi isolada pela primeira vez em 1950, sendo caracterizada com massa molecular de $4882 \mathrm{kDa}$ e pl 9,5, composta por 42 aminoácidos (GONÇALCES \& ARANTES, 1956; LAURE, 1975). Esta molécula 
contém 11 resíduos básicos (9 lisinas, 2 argininas), é estabilizada por 6 cisteínas, que fazem 3 ligações dissulfeto (Cys4-Cys36, Cys11-Cys30 e Cys1837) conforme observado na figura 3 .

Figura 3: Representação da estrutura tridimensional molecular da crotamina, evidenciando as pontes dissulfeto em amarelo.

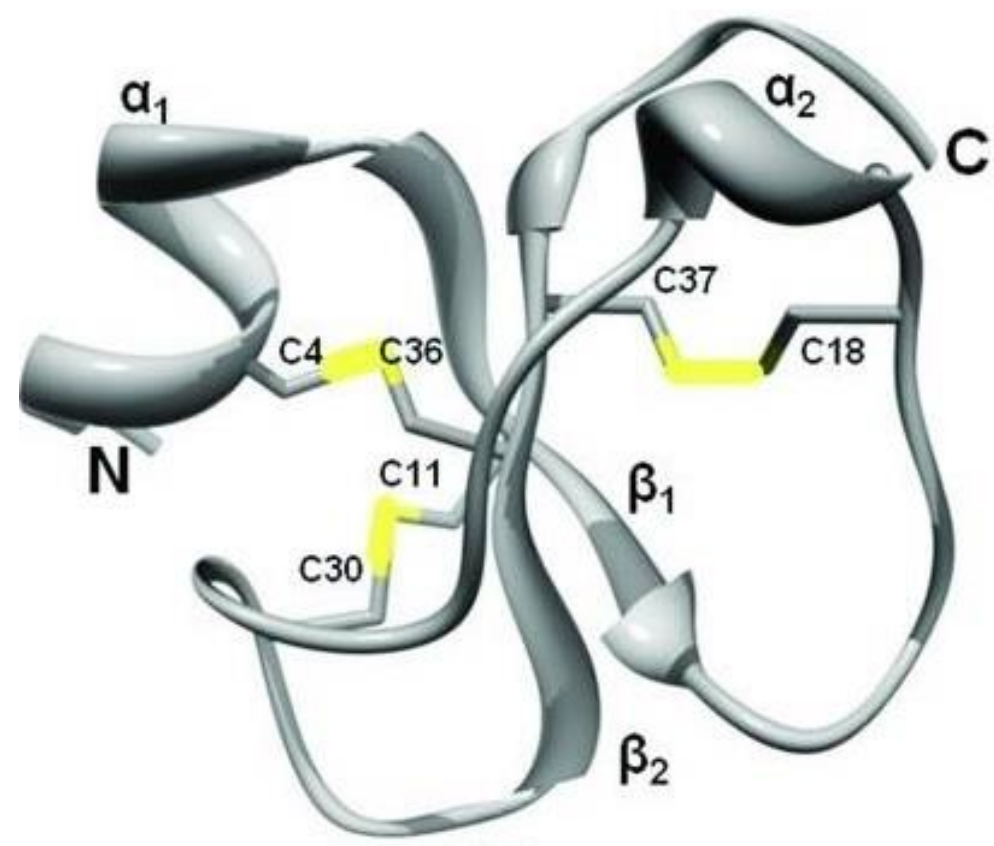

Fonte: Coronado, 2013

$\mathrm{Na}$, figura 4, podemos observar que as isoformas de crotamina são bastante semelhantes, uma vez que a diferença se dá por uma troca de leucina por isoleucina, troca que acontece curiosamente no veneno de C.d. ruruima (DOS SANTOS et al., 1993).

A crotamina é descrita como tendo diversas atividades biológicas, como a ação miotóxica em células musculares esqueléticas, o efeito desgranulador dos mastócitos, liberando histamina (OWNBY, 1998; MANCIN et al., 1997; MANCIN et al., 1998). Também já foi detectado atividade antiplasmódica (MALUF, 2016), antifúngica, contra Candida albicans (YAMANE, 2012) e antihelmíntica (DAL MAS, 2016).

Além disso, a crotamina também já foi descrita como tendo atividade antimicrobiana (YOUNT et al., 2009), e este mecanismo estaria relacionado à 
presença de cargas positivas em sua estrutura molecular (TORRES, 2004). Peptídeos catiônicos, como a crotamina, têm afinidade por lipopolissacarídeos, que são basicamente os principais componentes das membranas celulares externas de bactérias Gram-negativas. Como a crotamina apresenta grande semelhança com as $\beta$-defensinas em sua estrutura molecular, esta, foi classificada como antimicrobiana também, uma vez que estes peptídeos são antimicrobianos naturais produzidos por animais (NICASTRO et al., 2003). Estudos preliminares com a crotamina sugeriram que esta teria a capacidade de interferir com a membrana celular (SIEBER, 2014), fazendo com que estas membranas se desestabilizem e rompam através de porosidades causadas pela interação da crotamina. Posteriormente esta interação foi confirmada com o uso de membranas fosfolipídicas artificiais (COSTA et al., 2014). De acordo com as porosidades em membranas, entende-se então que a crotamina realiza a atividade bactericida por um processo mecânico, o que torna altamente improvável a aquisição de resistência por parte de micro-organismos, uma vez que esta resistência normalmente foca vias bioquímicas (como por exemplo, a $\beta$-lactamase). Moléculas de cDNA que codificam peptídeos similares á crotamina e a outras $\beta$-defensinas já foram detectadas em outras espécies de serpentes (CORREA \& OGUIURA, 2013).

Figura 4: Alinhamento e sequência de Crotamina (Cro Cdt) e crotamina-símile (Cro-símile Cdr), mostrando as áreas conservadas e a qualidade. A seta vermelha indica a mutação encontrada.

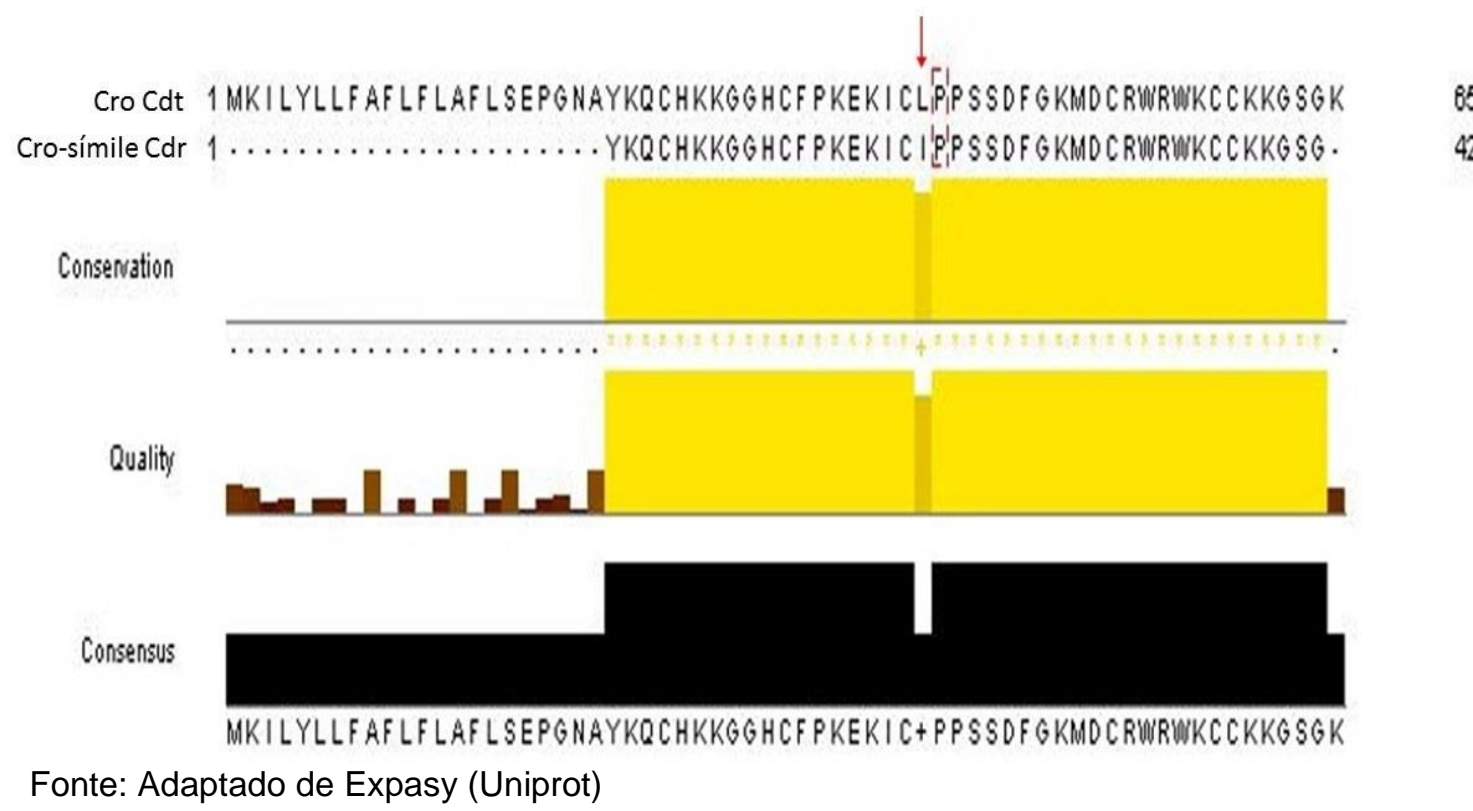


A atividade antimicrobiana da crotamina de $C$. $d$. $t$. já foi mostrada anteriormente em Escherichia coli, onde os resultados foram promissores. Foi mostrada também em Staphylococcus aureus, porém numa intensidade reduzida (OGUIURA, 2011). Estudos recentes identificaram componentes similares à crotamina e $\beta$-defensinas em outras espécies de serpentes (NICASTRO et al., 2003; CORREA \& OGUIURA, 2013). No entanto, pouco se sabe a respeito da atividade destas toxinas e se tem efeito miotóxico e/ou antimicrobiano. Uma investigação mais aprofundada do efeito antimicrobiano da crotamina e de seus análogos permitiria identificar novos candidatos a fármacos para combater infecções e impedir o surgimento de resistência bacteriana.

\section{METODOLOGIA}

\subsection{Material}

O pool de veneno liofilizado de $C$. $d$. $t$. foi cedido gentilmente pelo Instituto Butantan,

O pool de veneno liofilizado de C. $v$. foi cedido gentilmente pela empresa Venom Supplies (Tanunda, Austrália).

A fração crotamina-símile de $C$. $d$. $r$. foi cedida gentilmente pelo Dr. Claudio Fontes Souza.

\subsection{Anticorpos para Ensaios imunoenzimáticos}

O anticorpo policlonal, anti-crotamina, produzido em coelha, utilizado nos ensaios de ELISA, foi cedido gentilmente pela Dra. Nancy Oguiura do Instituto Butantan. 


\subsection{Cepas Bacterianas}

As bactérias Escherichia coli DH5a (E. coli), Micrococcus luteus (M. luteus) e Klebsiella pneumoniae (K. pneumoniae) e Staphylococcus aureus (S. aureus), foram cedidas gentilmente pela Dra. Nancy Oguiura, do Instituto Butantan.

\subsection{ELISA (Enzyme-linked imuno sorbent assay) para detecção de crotamina-símile}

Esta técnica foi descrita em 1971, por ENGVALL \& PERLMANN, que utilizaram $\lg$ de coelho como antígeno, que foi reconhecido por anti-lgG de coelho produzido em ovelha, sendo então adotada como técnica de quantificação de antígenos e/ou anticorpos mundo afora.

Neste estudo, uma placa de 96 poços foi sensibilizada com $20 \mu \mathrm{g}$ de veneno bruto de $C$. $d$. t. e $C$. v. e $20 \mu \mathrm{g}$ de fração peptídica de $C$. $d$. r., diluído em tampão de sensibilização (carbonato bicarbonato $0,1 \mathrm{M} \mathrm{pH} \mathrm{8,8)} \mathrm{e} \mathrm{mantido}$ overnight a $4^{\circ} \mathrm{C}$.

Após sensibilização, a placa foi lavada 3X com TBS e bloqueada com leite em pó desnatado (Molico ${ }^{\circledR}$, Nestlé) a 3\% em TBS, por 1 hora a temperatura ambiente. Após lavagem, o anticorpo anti-crotamina foi incubado em diluição com titulações de 1:500 até 1:16.000 durante 90 minutos a temperatura ambiente.

Uma nova lavagem foi feita a fim de retirar os anticorpos livres, para então realizarmos a incubação com o anticorpo secundário conjugado a peroxidase (Sigma), por 1 hora a temperatura ambiente. Para revelação, a placa foi lavada novamente e foi realizada a detecção da reação antígeno $X$ anticorpo pelo uso do substrato cromogênico 3,3-,5,5- Tetrametilbenzidina (TMB). 
As placas foram mantidas em câmara escura por 20 minutos, e após este período foi adicionado $50 \mu \mathrm{L}$ da solução de parada $(\mathrm{HCl} \mathrm{0,25} \mathrm{M).} \mathrm{A} \mathrm{leitura}$ da placa foi realizada em leitor de placas a $450 \mathrm{~nm}$.

\subsection{Fracionamento dos venenos crotálicos}

\subsubsection{Cromatografia de Exclusão molecular}

A técnica de cromatografia por exclusão molecular ou gel filtração, baseia-se na separação das moléculas a partir do seu volume hidrodinâmico ou massa molecular. Para tal, utilizou-se coluna Superdex 75 10/300 GL (GE) acoplada ao equipamento ÄKTA Purifier. Na coluna previamente equilibrada com fase móvel formiato de amônio 200 mM pH 3.0 (C. v.) ou fosfato de sódio $20 \mathrm{mM} / \mathrm{NaCl} 500 \mathrm{mM} \mathrm{pH} \mathrm{7,5} \mathrm{(C.d.} \mathrm{t),} \mathrm{foi} \mathrm{injetado} 20 \mathrm{mg}$ de veneno bruto $C . v$. ou $30 \mathrm{mg}$ de veneno bruto de C.d.t., ressuspendido em $0,6 \mathrm{~mL}$ da fase móvel. O fluxo utilizado foi de $0,6 \mathrm{~mL} /$ minuto. As frações obtidas foram separadas, aliquotadas e congeladas imediatamente após o fracionamento.

\subsubsection{Cromatografia de Troca Catiônica}

Nesta técnica de fracionamento as moléculas são separadas a partir da sua carga. Assim, as proteínas que tivessem características aniônicas, seriam repelidas pela carga negativa da resina, e as moléculas que tivessem características catiônicas sofreriam adsorção, a ponto de serem eluídas somente com gradiente salino. Para tal, utilizou-se a coluna Resource $S^{\circledR}$ (Pharmacia) acoplada ao equipamento ÄKTA Purifier. Com a coluna

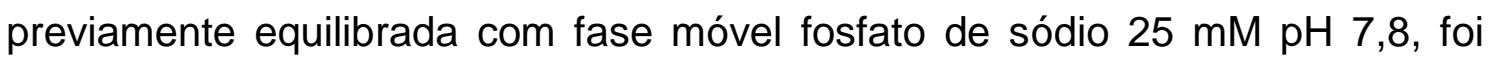
injetado $3 \mathrm{mg}$ da fração 4 de $C$. $d$. $t$, oriunda da cromatografia de exclusão molecular, diluída em $0,6 \mathrm{~mL}$ de fase móvel. No decorrer da corrida foi utilizado um gradiente de 0 a $50 \%$ de fosfato de sódio $+\mathrm{NaCl} 2 \mathrm{M} \mathrm{pH}$ 7.8. O fluxo foi mantido a $1 \mathrm{~mL} /$ minuto. As frações obtidas foram separadas e congeladas imediatamente. 
Com o objetivo de fazer o desalting, as amostras obtidas por esta técnica foram dialisadas em membrana benzoilada com cut off de $3 \mathrm{kDa}$ ou com Amicon ${ }^{\circledR}$ Millipore de $3 \mathrm{kDa}$ frente a HOAc $0,01 \%$ e posteriormente liofilizadas.

\subsubsection{Cromatografia de Fase Reversa}

Nesta técnica a separação das moléculas ocorreu pela hidrofobicidade da coluna, sendo uma coluna apolar e fase móvel polar. Foi utilizado uma coluna C8 ${ }^{\circledR}$ (Vydac) e coluna semipreparativa apropriada acoplada ao HPLC (Shimadzu). Sendo utilizadas duas metodologias diferentes: a primeira, foi realizada com ácido fórmico $0,05 \%$ (fase móvel $A$ ), e na fase móvel $B, A C N$ $90 \%$. Para a segunda metodologia, utilizamos como fase móvel A, TFA 0,1\% e fase móvel B (ACN 66\% em A). Cerca de $2 \mathrm{mg}$ de crotamina foram utilizadas para as análises.

Assim que as amostras foram eluídas, foram imediatamente congeladas e liofilizadas.

\subsection{Eletroforese em gel da poliacrilamida (SDS-PAGE)}

A eficiência dos métodos de cromatografia foi avaliada qualitativamente por esta técnica, sob condições não redutoras, conforme descrito por LAEMMLI (1970). O gel de empilhamento foi preparado na concentração de 5\% de poliacrilamida e para o gel de resolução utilizou-se $15 \%$ de poliacrilamida. Como catalisadores da reação de polimerização, utilizou-se persulfato de amônio e N,N,N,N-tetrametil etilenodiamina (TEMED).

Após cada etapa de fracionamento, foi adicionado $10 \mu \mathrm{L}$ de tampão não redutor em $30 \mu \mathrm{L}$ de amostra.

Para cada poço aplicou-se $30 \mu \mathrm{L}$ de amostra que foram submetidos a eletroforese a 90 V. O gel então foi corado com Coomassie Blue G-250 ou por nitrato de prata. 


\subsection{Ensaios antimicrobianos}

Para a realização dos ensaios, as bactérias utilizadas neste estudo foram: E. coli, K. pneumoniae, S. aureus e M.luteus.

A cultura bacteriana foi mantida em placa de Petri com meio Luria Bertani (LB) ágar 1,5\%, sendo cultivadas em repique semanal em meio LB líquido, por $18 \mathrm{hs}, 37^{\circ} \mathrm{C}$, a $120 \mathrm{RPM}$ em agitador orbital. A relação utilizada para quantificar as bactérias, foi de 1 O. D. $(600 \mathrm{~nm})=8 \times 10^{8}$ células $/ \mathrm{mL}$ (SAMBROOK, 1989).

\subsubsection{Antibiograma - Difusão em gota}

A técnica de disco-difusão descrita pela primeira vez por BAUER \& KIRBY, 1966, foi utilizada para avaliarmos a suscetibilidade dos agentes antimicrobianos. Este método foi adaptado, para que ao invés, de usarmos a difusão em disco, usássemos a difusão em gota, onde cada placa recebeu 10 $\mu \mathrm{L}$ do peptídeo antimicrobiano a ser testado, partindo de uma concentração inicial de $10 \mathrm{mg} / \mathrm{mL}$ e efetuando diluições seriadas de fator 2, utilizando como controle positivo $\left(\mathrm{C}_{+}\right)$antibiótico e antimicótico (penicilina 1,56 U/mL, streptomicina $78 \mathrm{ng} / \mathrm{mL}$ e anfotericina $0,39 \mathrm{ng} / \mathrm{mL}$ ) e como controle negativo (C) utilizou-se ácido acético glacial 0,01\% (HOAc 0,01\%) pois foi utilizado com diluente das amostras.

Para o ensaio, foi produzido um inóculo em meio LB líquido onde as bactérias foram mantidas overnight. Para o acompanhamento do processo de duplicação bacteriano, foram realizadas leituras em $600 \mathrm{~nm}$, e pelo valor de densidade óptica obtido foi possível rastrear a fase de crescimento exponencial (fase log), de acordo com as curvas de crescimento para cada espécie, que já haviam sido estabelecidas em estudos anteriores

Para o preparo da placa foi adicionado $1 \mathrm{~mL}$ do inóculo em $9 \mathrm{~mL}$ de ágar LB $(1 \%)$ e a mistura foi homogeneizada cuidadosamente. 
Após a solidificação do meio, as frações foram diluídas em ácido acético glacial $0,01 \%$, e $10 \mu \mathrm{L}$ de cada amostra foi aplicada sob a placa e incubada a por $16-18 \mathrm{hs}$ a $37^{\circ} \mathrm{C}$. Os halos foram observados e a análise foi qualitativa, na qual a presença de halo era indicativo de inibição do crescimento bacteriano.

\subsubsection{Concentração inibitória mínima (CIM)}

A metodologia utilizada de XIAO e colaboradores (2006) foi modificada para avaliar a atividade antibiótica.

Foi feito um pré-inóculo a partir de 3 colônias em $3 \mathrm{~mL}$ meio TSB (Tryptic Soy Broth, $\operatorname{Kasvi}^{\circledR}$ ), deixando sob agitação de 120 RPM à $37^{\circ} \mathrm{C}$ overnight. Após o crescimento, um inóculo foi feito com $100 \mu \mathrm{L}$ do cultivo e $8 \mathrm{~mL}$ de TSB que foi deixado sob agitação de $120 \mathrm{RPM}$ à $37^{\circ} \mathrm{C}$ por 90 min até 3 hs. Para acompanhar o crescimento, verificamos a densidade óptica em espectrofotômetro em comprimento de onda de $600 \mathrm{~nm}$, até atingirem uma O.D. ótima, que corresponde a fase de crescimento logarítmica, determinada anteriormente a partir da curva do crescimento de cada espécie.

As bactérias foram centrifugadas a $3220 \mathrm{~g}$ por 10 min e lavadas com

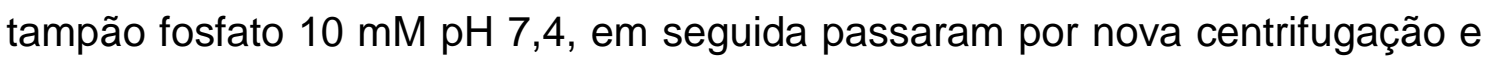
foram ressuspendidas em meio TSB $20 \%$, exceto a $E$. coli, que foi ressuspendida em TSB $30 \%$. A quantidade de células utilizadas para o ensaio foi de $4 \times 10^{5} \mathrm{UFC} / \mathrm{mL}$.

Em placa de 96 poços, foi feita a diluição seriada em triplicata, com $10 \mu \mathrm{L}$ de toxina testada e $90 \mu \mathrm{L}$, de meio, sendo equivalente a aproximadamente 205 $\mu \mathrm{M}$ iniciais. Como controle positivo foi utilizado antibiótico e antimicótico descrito anteriormente e somente bactérias como controle negativo. A placa foi incubada a $37^{\circ} \mathrm{C}$ em estufa com câmara úmida por $16-18 \mathrm{hs}$.

Após o período de incubação, a placa foi homogeneizada por 10 segundos e realizada a leitura em espectrofotômetro a $620 \mathrm{~nm}$, estes dados 
foram coletados no programa Excel e exportados para o programa Prisma, onde os dados foram tratados.

\subsection{Ensaio in vitro}

Para realização de ensaios de citotoxicidade, foi escolhida a linhagem celular 3T3, que foi desenvolvida a partir de fibroblastos de camundongos Swiss e adquirida da ATCC (American Type Cell Collection).

As células foram cultivadas em meio DMEM (Dulbecco's Modified Eagle's Medium) suplementado com 10\% de SFB (soro fetal bovino), 1\% de antibiótico e antimicótico $\left(\mathrm{GIBCO}^{\circledR}\right)$ até atingirem $80 \%$ de confluência. As células foram incubadas em estufa com $5 \%$ de $\mathrm{CO}_{2}$ a $37^{\circ} \mathrm{C}$ e atmosfera úmida.

\subsubsection{Citotoxicidade em células 3T3}

Os ensaios com as toxinas fracionadas foram realizados por método colorimétrico, onde foi utilizado o corante vital MTS (3-(4,5-dimethylthiazol-2-yl) -5-(3-carboxymethoxyphenyl) -2-(4-sulfophenyl) -2H-tetrazolium). Este teste indica a citotoxicidade que os materiais testados causam quando entram em contato com as células cultivada in vitro. $O$ ensaio avalia quantitativamente a viabilidade celular, quando incubamos as células com o corante MTS e o reagente acoplador de elétrons PMS (phenazine methosulfate). Avaliamos então a toxicidade de acordo com a absorbância do sal de formazan formado (MALICH, 1997).

Em microplacas de 96 poços foram semeadas $1 \times 10^{4}$ células por poço e incubadas em estufa com $5 \%$ de $\mathrm{CO}_{2}$ a $37^{\circ} \mathrm{C}$ e atmosfera úmida. Após 24 horas, a placa foi lavada com tampão fosfato (PBS) $\mathrm{pH} 7,4$ estéril, a fim de remover as possíveis células que não aderiram aos poços.

Foi então feita a diluição seriada da crotamina e crotamina-símile (diluída em meio de cultura) nos poços iniciando com a concentração de $5 \mathrm{mg} / \mathrm{mL}$. 
Como controle positivo foi utilizado (DMSO 10\%), controle negativo (somente células em meio de cultura) e branco (somente meio de cultura).

Posteriormente, decorridas 24 horas de incubação com a toxina, o meio de cultura foi retirado, e a placa foi lavada novamente com PBS estéril. Por fim, foi adicionada a solução corante vital MTS/PMS, na proporção 2:0,1 e a placa foi incubada por duas horas, em seguida foi realizada a leitura em espectrofotômetro a $490 \mathrm{~nm}$.

\subsection{Ensaio in vivo de paralisia do trem posterior em camundongos Swiss}

Este ensaio foi importante para avaliarmos a atividade biológica da crotamina, após os métodos cromatográficos. Utilizamos camundongos Swiss, machos e fêmeas, pesando entre 20 e $30 \mathrm{~g}$ e os separamos em grupos de controle negativo (somente salina $0,9 \%$ ), crotamina purificada por troca catiônica e por dois métodos em fase reversa. A concentração de crotamina utilizada nos ensaios foi de $300 \mu \mathrm{g} / \mathrm{kg}$. A toxina foi considerada com atividade biológica preservada quando capaz de provocar a paralisação e espasmos dos membros posteriores dos camundongos, indicando a miotoxicidade, sua principal atividade.

A certificação da experimentação foi aprovada pela Comissão de Ética no uso de Animais (CEUA/IPEN) e está registrada sob n 191/17.

\section{ANÁLISE E DISCUSSÃO DOS RESULTADOS}

\subsection{ELISA Indireto (Indirect Enzyme linked ImmunoSorbent Assay)}

O ensaio de ELISA indireto foi realizado com o objetivo de identificar as toxinas com estrutura crotamina-símile. Portanto, utilizou-se o veneno total de C.d t., $C$ v. e a fração de C.d.r., mostrado no gráfico abaixo. 
Figura 5: Imunorreatividade realizada com $20 \mu \mathrm{g}$ de veneno total de venenos crotálicos e fração peptídica de C.d.r..

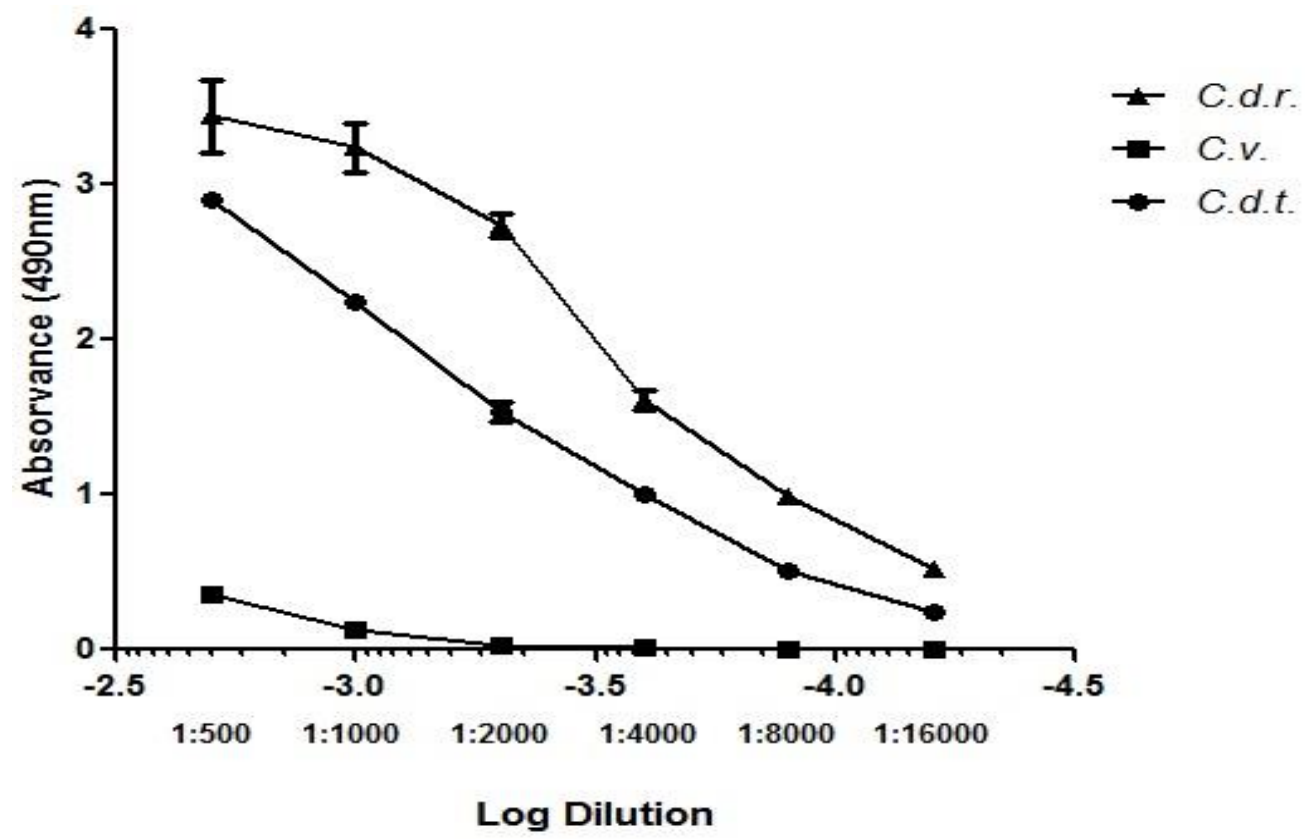

Fonte: A autora

Foi feita diluição seriada com o anticorpo policlonal anti-crotamina, num intervalo de 1:500 até 1:16.000. Pode-se observar que houve um reconhecimento decrescente e contínuo de acordo com as diluições realizadas tanto em C.d.t. quanto em C.d.r.

Com relação ao reconhecimento do veneno bruto de C.d.t., percebe-se que houve imunorreatividade até a titulação de 1:16.000, sugerindo maior afinidade entre antígeno $X$ anticorpo ou maior concentração de antígeno na amostra, se comparado ao veneno bruto de C.v. A baixa imunorreatividade do veneno de $C$. $v$. sugere uma menor quantidade de crotamina-símile, como mostrado nas etapas de fracionamento deste veneno, fato também observado por VIALA et al., 2015, pela técnica de western blot. Ainda podemos contar com outra variável, de que a molécula crotamina-símile de C.v. apresente ligeiras modificações conformacionais, que podem ter dificultado seu reconhecimento.

A fração Crotamina-símile de C.d.r. apresentou maior imunorreatividade, isto se deve ao fato de estar $5 \mathrm{X}$ mais concentrada, se comparada a quantidade 
de crotamina que encontramos no veneno de C.d.t., que representa aproximadamente $20 \%$ do veneno bruto (LAURE, 1975).

\subsection{Isolamento da Crotamina a partir do veneno de Crotalus durissus terrificus}

\subsubsection{Cromatografia Líquida - Exclusão molecular do veneno bruto de $C$. d. $t$. e SDS-PAGE $15 \%$ das frações coletadas da cromatografia}

A fim de iniciar o processo de fracionamento, foi realizada cromatografia de exclusão molecular conforme descrito anteriormente. Onde utilizou-se 30 mg de veneno bruto.

Figura 6: Fracionamento de $30 \mathrm{mg}$ de veneno bruto de C.d.t em coluna Superdex 75 10/300 GL. Os números de 1 a 5 indicam as frações coletadas. A fração $4^{*}$ corresponde a Crotamina

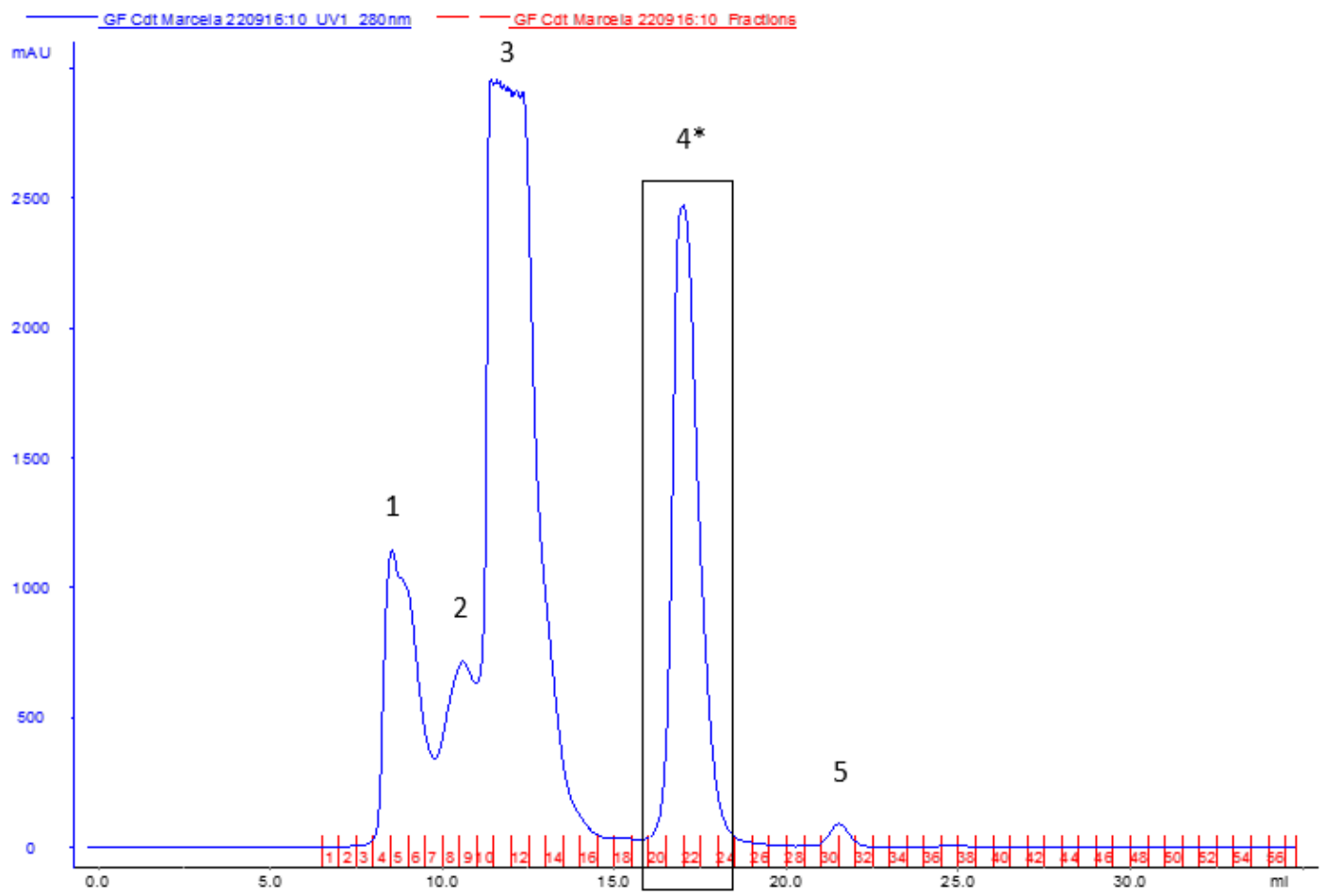

Fonte: A autora

Para verificar a qualidade do fracionamento foi realizada eletroforese em gel de poliacrilamida $15 \%$, no qual $30 \mu \mathrm{L}$ de cada fração obtida foram aplicados em condições não redutoras no gel. 
A figura 7 mostra a eficiência de separação pela técnica de exclusão molecular, na qual é observada um perfil eletroforético com um padrão de distribuição de bandas, primeiramente representadas pelas proteínas de alta massa molecular, seguidas de componentes com uma redução gradual de tamanho.

Figura 7: SDS-PAGE 15\% - M (padrão de massa molecular); 1 (convulxina); 2 (giroxina); 3 (crotoxina); 4 (crotamina); 5 (crotalfina).

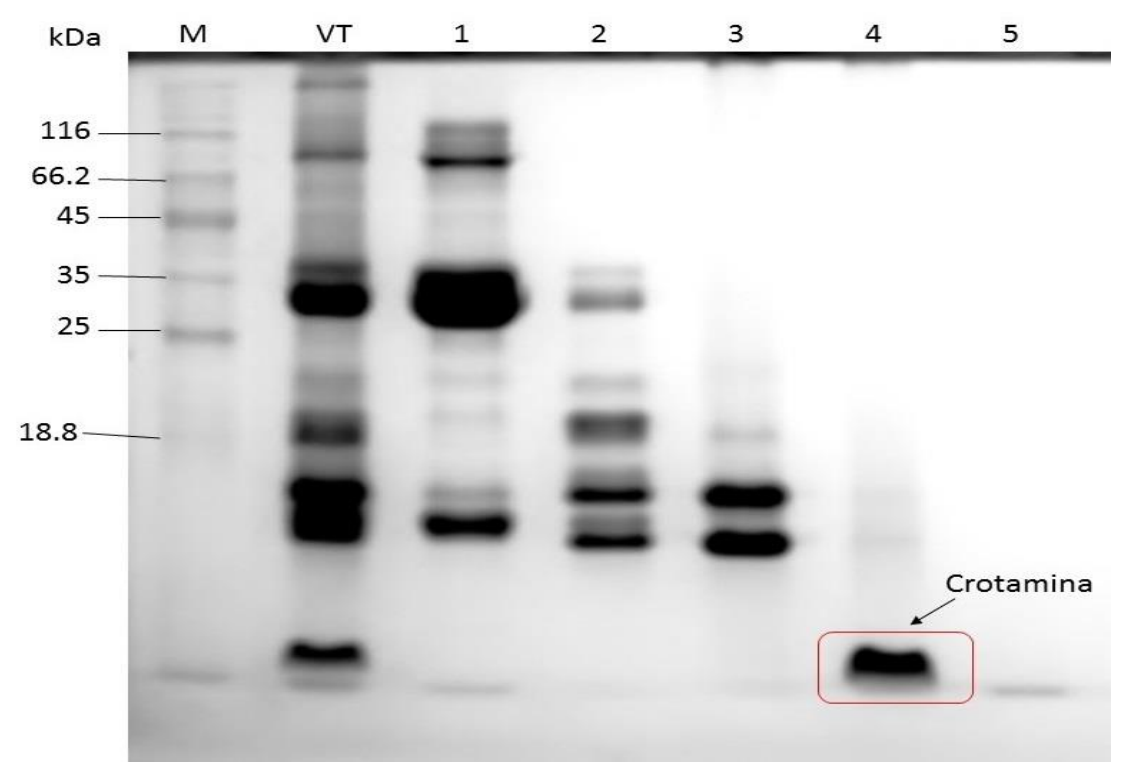

Fonte: A autora

As frações de baixa massa molecular, que foram o enfoque deste estudo, estão indicadas na fração de número 4 . A técnica de SDS-PAGE não identificou a fração número 5 , por conta da baixíssima massa molecular. LOURENÇO A. Jr. e colaboradores (2013) observaram perfis semelhantes quando fracionaram o mesmo veneno, garantindo a eficiência do método.

Pelo perfil cromatográfico obtido e a distribuição de bandas distribuídas pela eletroforese, representada pelas proteínas convulxina (1), giroxina (2), crotoxina (3), crotamina (4) e crotalfina (5) foi observado que em apenas uma etapa de fracionamento, ocorre a eluição da crotamina com baixo grau de contaminação pela toxina majoritária do veneno, a crotoxina, o que corrobora com o trabalho de HERNANDEZ-OLIVEIRA et al., 2005. 


\subsubsection{Cromatografia Líquida - Troca catiônica da fração 4 de C.d.t. e SDS- PAGE 15\% da fração Crotamina (4b).}

A fração 4 proveniente da cromatografia de exclusão molecular, mostrada anteriormente, foi injetada em coluna de troca catiônica, conforme metodologia do item 3.5.2.

Figura 8: Troca catiônica do Pico 4 proveniente da Exclusão molecular do veneno de $C$. d. t. A fração $4 a$ representa as moléculas não adsorvidas e $4 \mathrm{~b}$ representa as moléculas que se ligaram a resina aniônica e foram eluídas apenas com gradiente de $\mathrm{NaCl}$.

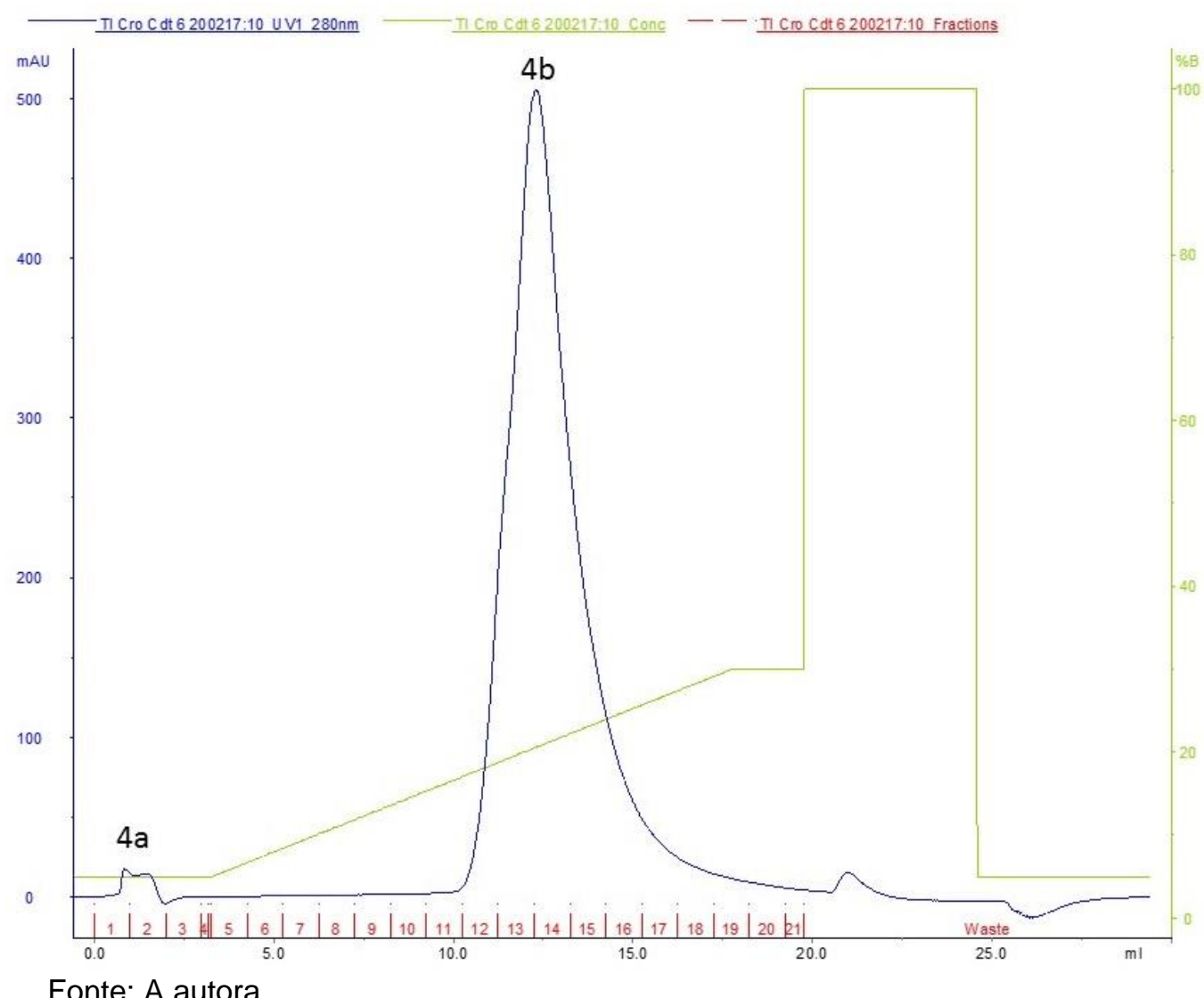

Fonte: A autora

O cromatograma (figura 8) demonstrou alto grau de pureza da crotamina, perfil que apresenta semelhança com os dados obtidos por OLIVEIRA, 2015. A técnica permitiu a separação de proteínas com diferentes pontos isoelétricos, no qual a fração 4a que não adsorveu a resina representa uma fração aniônica, e a fração 4b, que interagiu com a resina, representa uma fração catiônica, como a crotamina. 
Figura 9: SDS-PAGE feito com a fração $4 b$ do gel, correspondente a crotamina. M: padrão de massa molecular.

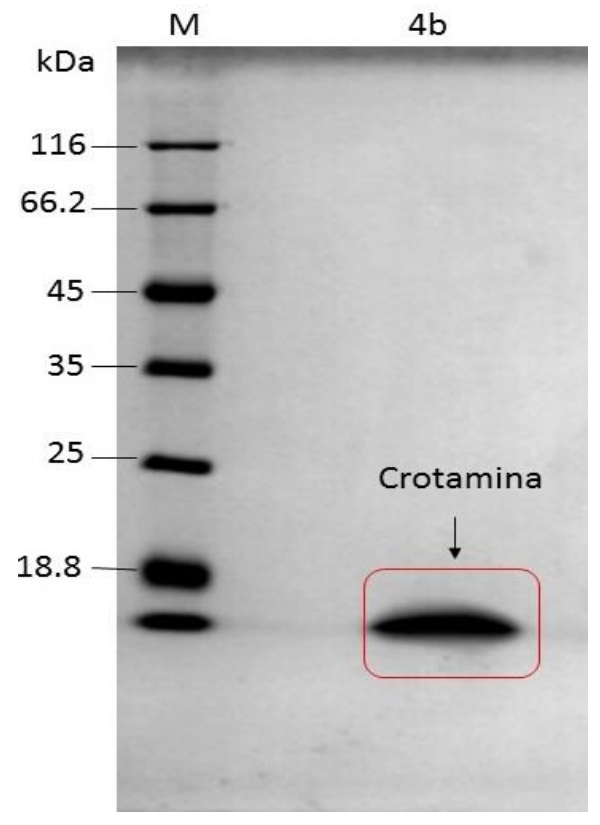

Fonte: A autora

Isto é confirmado no SDS-PAGE onde nota-se a banda bem definida de baixa massa molecular, que corresponde a crotamina purificada em 2 etapas cromatográficas.

\subsection{Antibiograma de crotamina após Troca lônica}

O antibiograma é um ensaio qualitativo, que indica a atividade antimicrobiana mediante a presença de um halo inibitório formado, que pode-se notar na figura 10.

A crotamina foi ativa em todas as espécies, porém mostrando halos com diferentes intensidades, o que demonstra uma seletividade do peptídeo estudado. Nos dados obtidos, a crotamina mostrou maior ação em bactérias Gram positivas (M. luteus e $S$. aureus), o que está em consonância com a literatura, uma vez que já foi descrito atividade antimicrobiana em $S$. aureus por YOUNT, (2009). Sendo um peptídeo antimicrobiano catiônico, a atividade em bactérias Gram positivas pode estar atrelada à presença de ácido teicóico quando testadas em outros AMP's catiônicos (GIRAL et al., 2006). 
Figura 10: Antibiograma em diferentes espécies bacterianas, onde A: K. pneumoniae; B: S. aureus; C: E. coli; D: M. luteus. Os halos destacados são provenientes da atividade da crotamina e o halo central do controle positivo (atb-antibiótico).
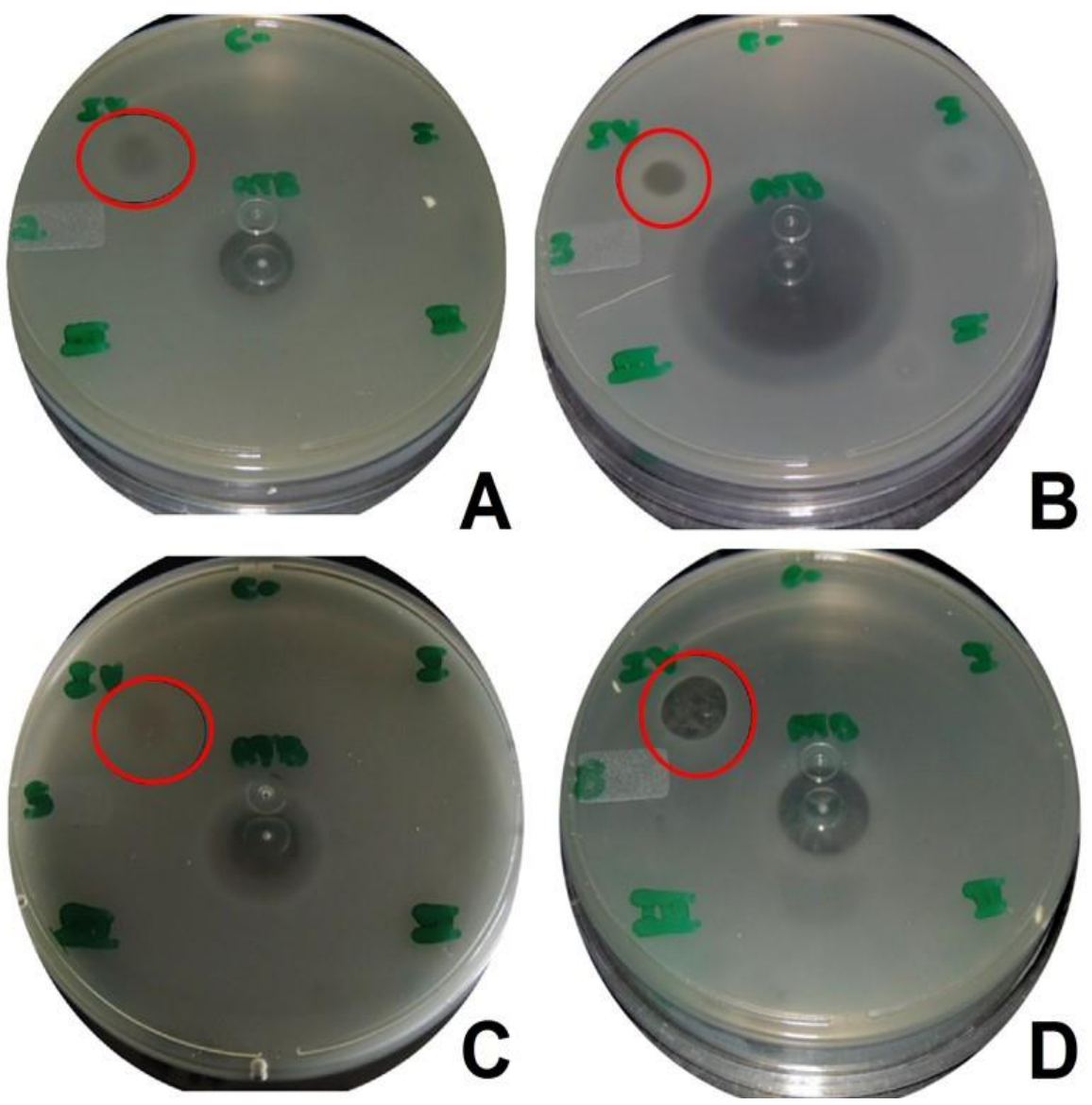

Fonte: A autora

\subsection{Análise de estabilidade da atividade miotóxica e antimicrobiana da crotamina}

\subsubsection{Cromatografia de fase reversa com $90 \%$ de ACN}

Com o objetivo de otimizarmos as técnicas de purificação da crotamina, foi realizado um refracionamento em coluna de fase reversa da fração oriunda da exclusão molecular. Como fase móvel, foi utilizado o ácido fórmico 0,1\%, e um gradiente, até $90 \%$ de $A C N$, durante 20 minutos. A purificação se mostrou bastante eficiente, com alto grau de pureza da amostra. 
Figura 11: Cromatograma de fase reversa, realizada em comprimento de onda de $280 \mathrm{~nm}$, indicando em vermelho o pico de crotamina purificada

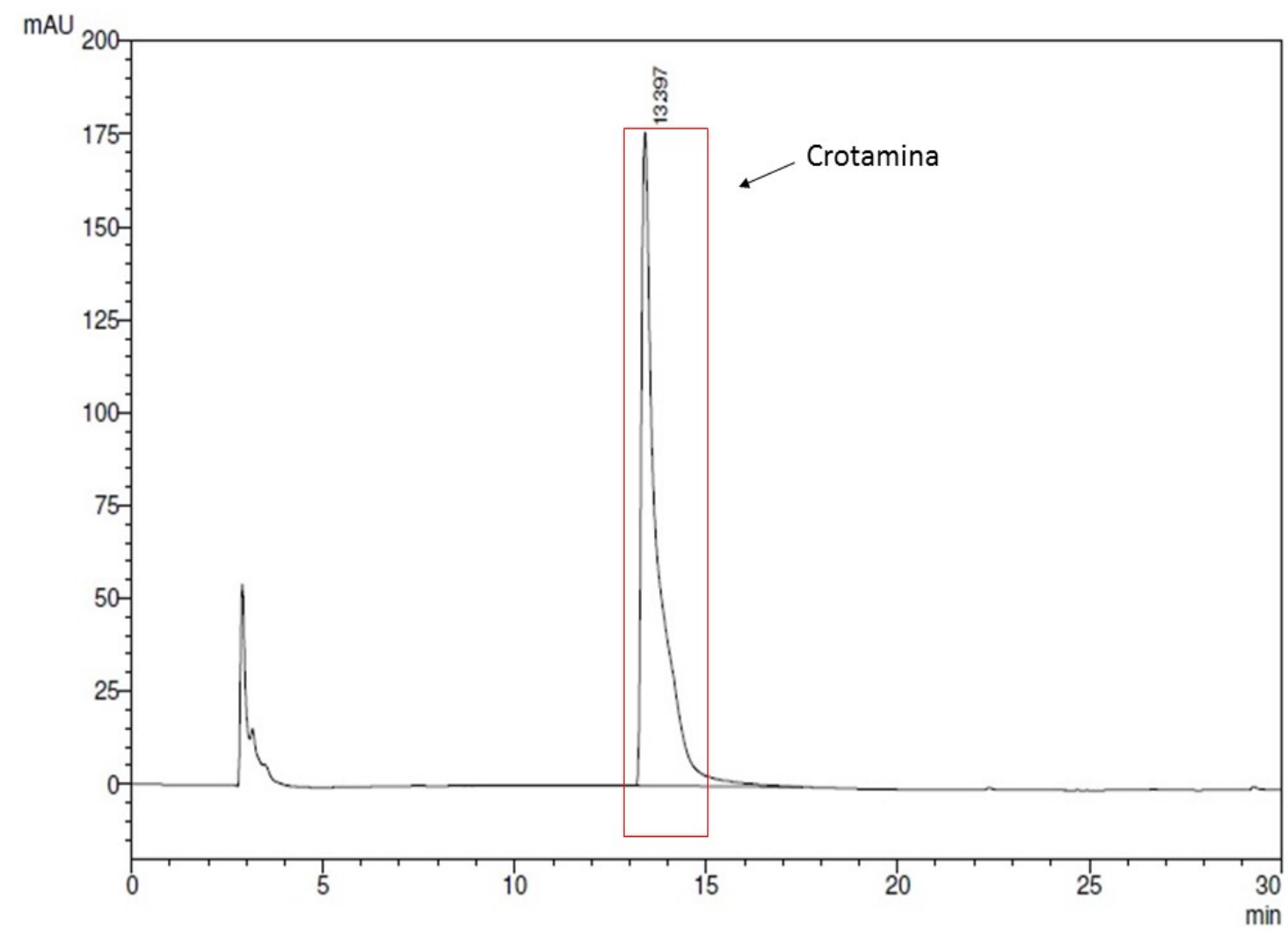

Fonte: A autora

Porém, ao ser testada no antibiograma de difusão em gota, a crotamina purificada por esta metodologia perdeu sua atividade antimicrobiana. A mesma amostra, foi submetida ao ensaio in vivo para verificar a atividade miotóxica. Entretanto, não foi observada tal atividade biológica.

Este processo pode ocorrer, pois é sabido que os solventes orgânicos podem desnaturar proteínas, modificando suas estruturas secundárias, ou terciárias (BOBALY, 2016).

O protocolo de purificação já estabelecido da crotamina, conta inicialmente com uma cromatografia de gel filtração, onde utiliza-se uma coluna Superdex 75 10/300 GL, tendo como segundo passo, a cromatografia de troca catiônica (Resource S) e posteriormente o processo de desalting ou diálise e por fim a liofilização (MANCIN, 1998; FAURE, 1988). 


\subsubsection{Cromatografia de fase reversa com $66 \%$ de $A C N$.}

Com a fração 4 proveniente da exclusão molecular, foi adotada uma nova metodologia, onde utilizou-se TFA 0,1\% como fase móvel A, e 66\% de ACN, como fase móvel B. A figura demonstra a eficiência da metodologia adotada na purificação da crotamina e ainda possibilita ver duas isoformas do peptídeo.

Figura 12: Cromatograma de fase reversa realizada com comprimento de onda de $280 \mathrm{~nm}$, com pico de crotamina indicado em vermelho, mostrando duas isoformas.

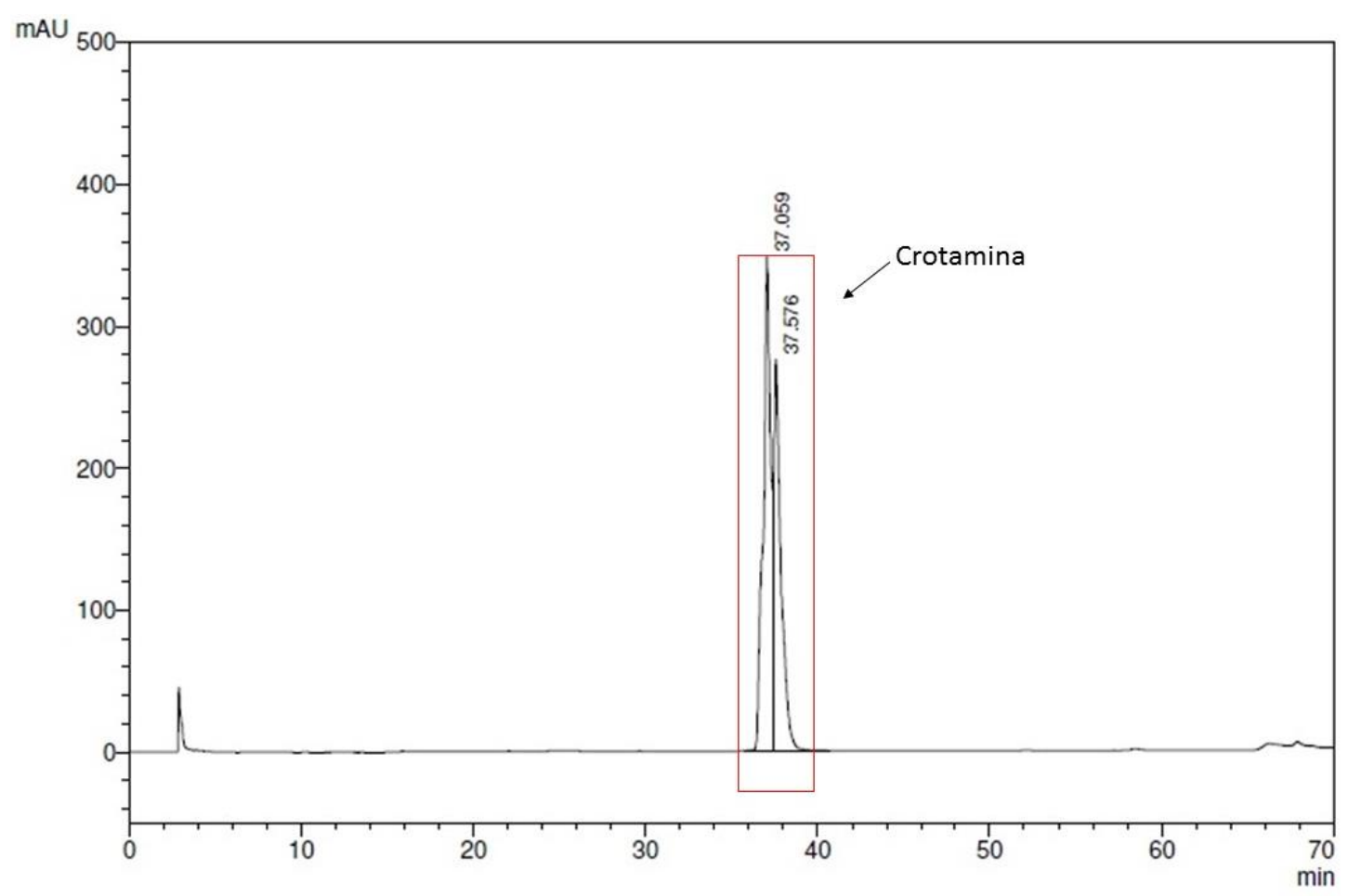

Fonte: A autora.

A cromatografia com $66 \%$ de ACN mostrou-se tão eficiente, em termos de pureza, quanto a realizada com maior porcentagem de solvente orgânico, como indicadas pelas figuras 11 e 12. Isso também foi confirmado pelo SDSPAGE a $15 \%$, onde se observou que em todas as frações coletadas, havia somente a presença de crotamina, não sendo possível visualizar nenhuma forma contaminante, destacando então a pureza do peptídeo estudado (figura 13). 
Figura 13: SDS-PAGE das frações obtidas da fase reversa com ACN $66 \%$, onde $M$ (padrão de massa molecular), 1, 2, 3, 4 picos coletados com diferentes concentrações de crotamina.

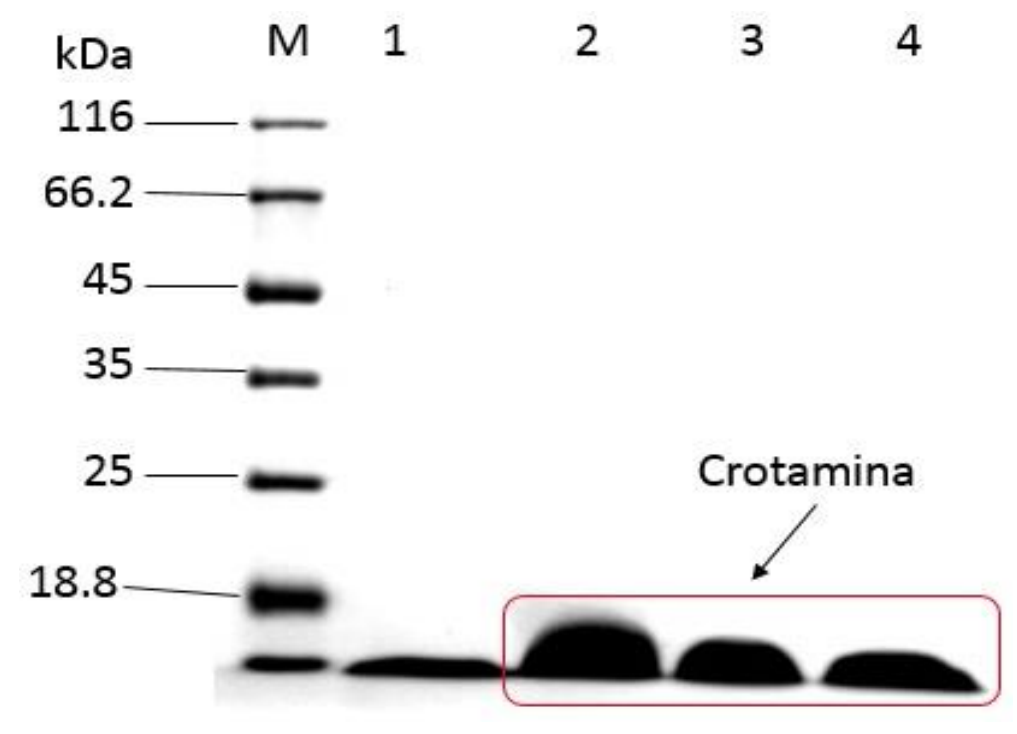

Fonte: A autora

Para garantir o máximo de preservação da amostra, foi realizado o pool destas frações, que foram congeladas e liofilizadas. Esta metodologia de purificação da crotamina, padronizada por PONCE-SOTO, 2007, confirma a rapidez e a facilidade de obter o peptídeo purificado em apenas duas etapas cromatográficas, ainda permitindo a liofilização direta, uma vez que a fase móvel é totalmente volátil e livre de sal, dispensando etapas de diálise.

A amostra purificada com $66 \%$ de $A C N$ foi testada em antibiograma por difusão em gota nas quatro espécies bacterianas, e, não foi observada formação de halo. Este resultado demonstrou que a presença de um solvente orgânico influenciou diretamente na atividade antimicrobiana.

\subsection{Ensaio in vivo de paralisia do trem posterior de camundongos Swiss.}

A fim de testar a atividade miotóxica da crotamina quando exposta a solventes orgânicos, realizamos este ensaio, com o uso do peptídeo liofilizado, ressuspendido em salina 0,9\% estéril. Os animais foram organizados em 3 grupos, com 4 animais cada. Sendo grupo 1 controle negativo, representado 
pelos camundongos que receberam injeção via intraperitoneal somente de solução salina $0,9 \%$ estéril, grupo 2, crotamina purificada por troca catiônica e grupo 3 crotamina purificada por fase reversa $(66 \% \mathrm{ACN})$.

Pelos resultados obtidos, não houve diferença entre os animais dos grupos 2 e 3, na qual foi observada a atividade mais notável da crotamina, a presença de espasmos e paralisia muscular flácida (VIEIRA et al., 2006).

Tabela 2: ensaio de paralisia representado por grupos, onde $\mathrm{C}$ - (controle negativo), Cro TI (crotamina purificada por troca catiônica) e Cro RP (crotamina purificada por fase reversa.

\begin{tabular}{l|l} 
Grupo & Paralisia do trem posterior \\
\hline C- & Ausente \\
Cro $T I$ & Após 10 minutos \\
Cro RP & Após 15 minutos
\end{tabular}

Fonte: A autora

A crotamina purificada por fase reversa manteve a sua atividade miotóxica, semelhante a que encontramos na crotamina purificada por troca catiônica, como podemos comparar pela tabela 2 e figura 14. Porém, ao realizarmos o antibiograma, não foi observada a atividade antimicrobiana da crotamina frente as espécies testadas. Sugere-se então que a região do peptídeo responsável por tal atividade seja mais susceptível ao processo de desnaturação por solventes orgânicos, uma vez que a crotamina é extremamente catiônica e por interagir com a bicamada fosfolipídica das células bacterianas este sítio ativo antimicrobiano estaria mais superficial na molécula.

De acordo com a literatura, peptídeos antimicrobianos em $\mathrm{pH}$ fisiológico tem seus domínios apolares interagindo com o core hidrofóbico de microorganismos (CRUZEIRO-SILVA et al., 2007; PESCHEL \& SAHL, 2006; SATO \& FEIX, 2006). Logo, os resíduos hidrofóbicos da crotamina estão expostos a 
solventes (CORONADO et al., 2013), o que reforça a hipótese de o sítio ativo antimicrobiano estar exposto e não estar vinculado ao sítio ativo miotóxico. Logo, os resultados observados na tabela 2 e na figura 14, confirmam a atividade miotóxica preservada da crotamina.

Figura 14: Camundongos Swiss com paralisia no trem posterior. Onde A) Cro TI; B) Cro RP.

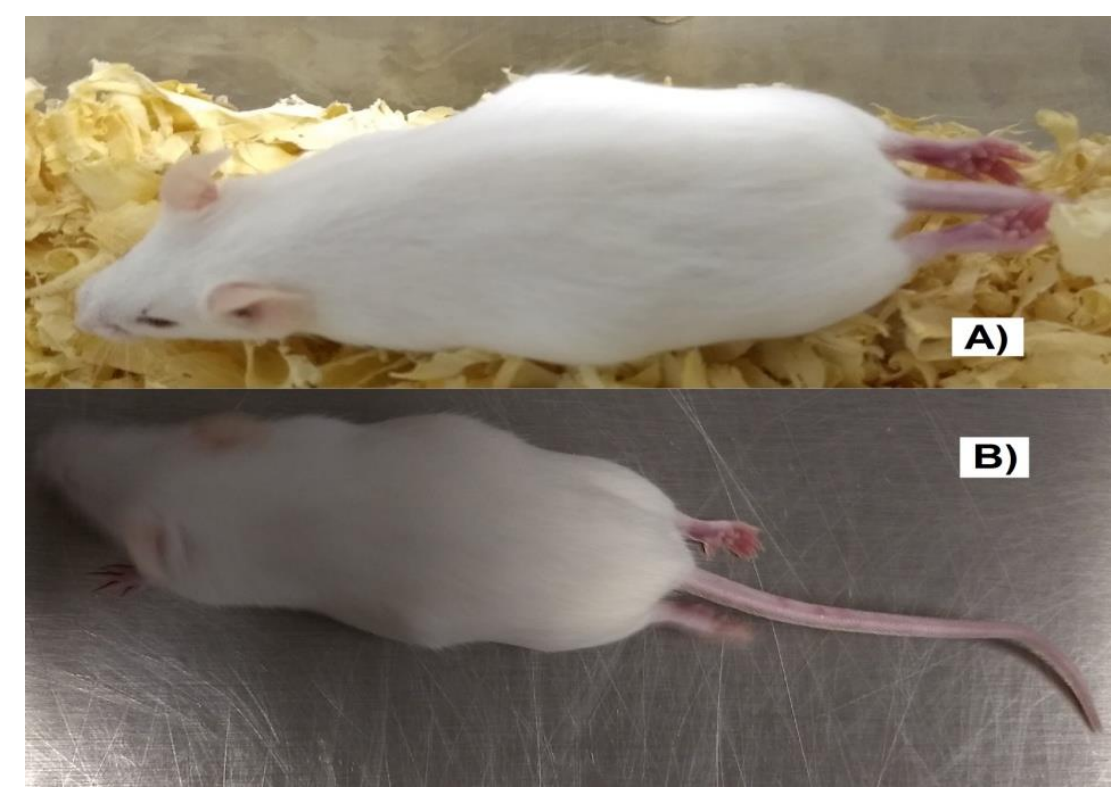

Fonte: A autora

\subsection{Purificação do veneno de Crotalus vegrandis}

\subsubsection{Exclusão molecular do veneno bruto de C.v. e SDS-PAGE das frações coletadas.}

Conforme descrito anteriormente, foi utilizado $20 \mathrm{mg}$ de veneno bruto, diluídos em 0,6 $\mathrm{mL}$ na fase móvel apropriada, o cromatograma gerou o gráfico observado na figura 15 .

Os dados do perfil cromatográfico comprovam a eficiência da técnica, juntamente com os dados de MOORE et al., 2015. Foi observado tempos próximos de retenção da molécula identificada por VIALA et al., $2015 \mathrm{com}$ cerca de $5 \mathrm{kDa}$, reafirmando a hipótese de uma molécula crotamina-símile. 
Figura 15: Fracionamento de $20 \mathrm{mg}$ de veneno bruto de C.v. em coluna Superdex 75 10/300 GL. SDS-PAGE das frações da exclusão molecular, indicando a fração crotamina-símile.

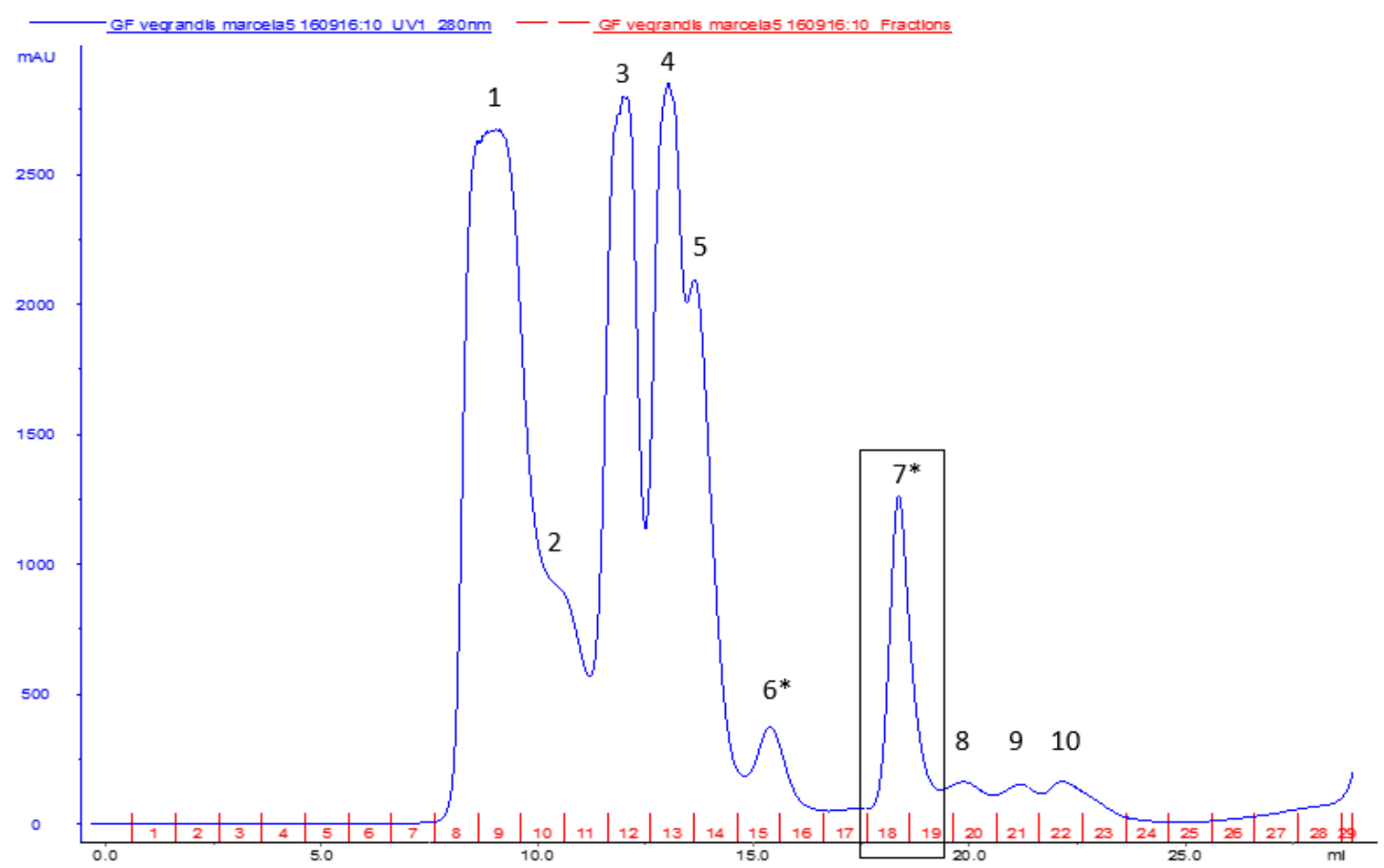

Fonte: A autora

Após o fracionamento, foi feito um SDS-PAGE a 15\% para verificar a qualidade do fracionamento, onde $30 \mu \mathrm{L}$ das frações obtidas foram aplicadas em condições não redutoras no gel.

Figura 16: SDS-PAGE a 15\%. M: padrão de massa molecular. VT: veneno total. 1-9: picos coletados da cromatografia. A fração 6,7 e 8 , indica a amostra mais promissora para realização dos próximos ensaios.

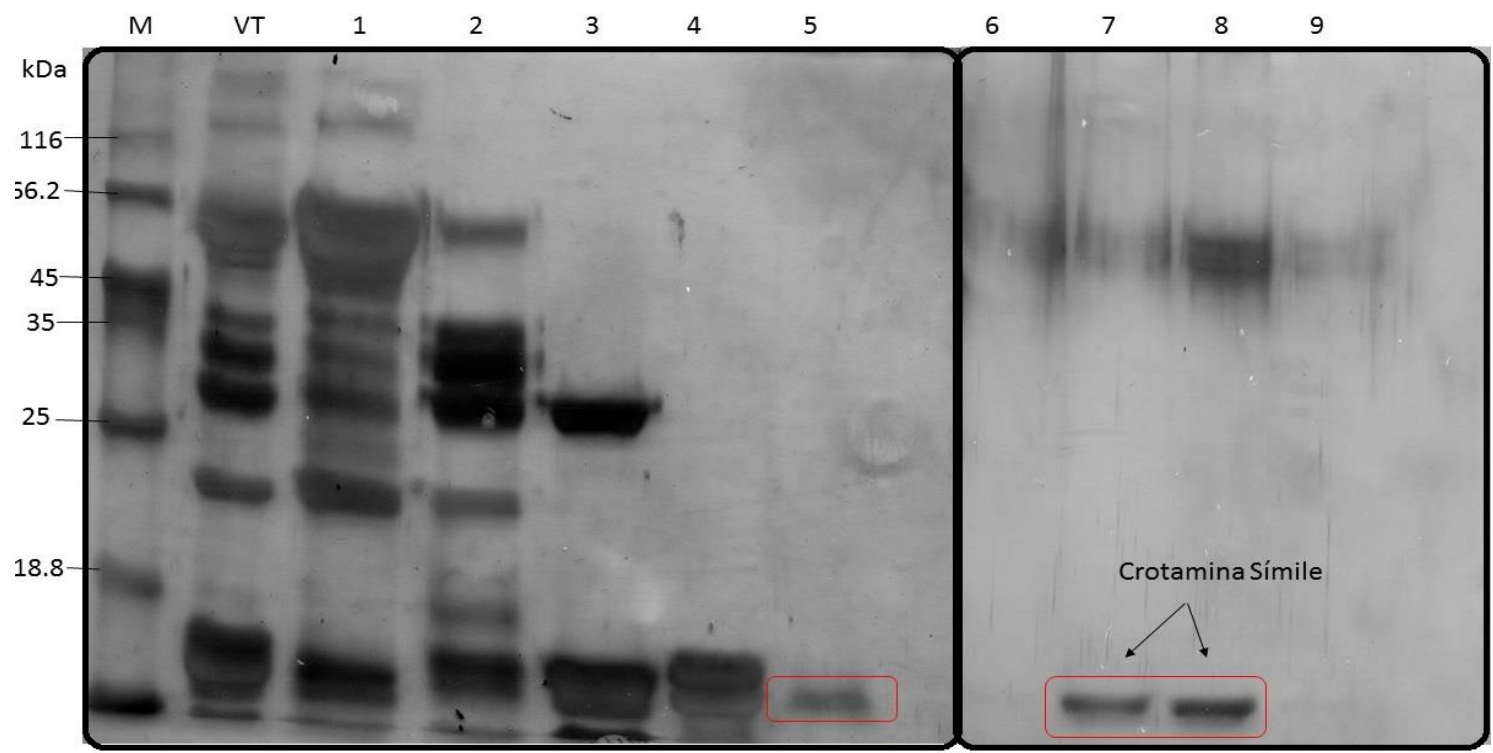

Fonte: A autora 
As figuras 15 e 16 mostram a eficiência da separação pela técnica de exclusão molecular, bem como as toxinas constituintes do veneno. As frações consideradas peptídicas, que foram o foco deste estudo, estão localizadas nas frações de número $5,6,7$ e 8 . A fração $7^{\star}$, foi a mais promissora para realização dos próximos ensaios. A técnica de SDS-PAGE confirmou também a separação por exclusão molecular, visto que as moléculas vão tendo menor massa molecular a cada fração. A técnica não identificou a fração de número 9 e 10 por conta das baixíssimas massas moleculares.

\subsubsection{Cromatografia de troca catiônica da fração 7 de C. v. e SDS-PAGE a $15 \%$ da fração coletada}

Utilizando a fração 7 proveniente da cromatografia de exclusão molecular, mantendo a metodologia do item 3.5.2., foi feita uma nova etapa de fracionamento, para obter a fração com menos contaminantes.

Figura 17: Troca catiônica da fração 7 proveniente da Exclusão molecular do veneno de C. v. A fração $7 \mathrm{a}$ representa as moléculas não adsorvidas e $7 \mathrm{~b}$ representa as moléculas que se ligaram a resina aniônica e foram eluídas apenas com gradiente de $\mathrm{NaCl}$.

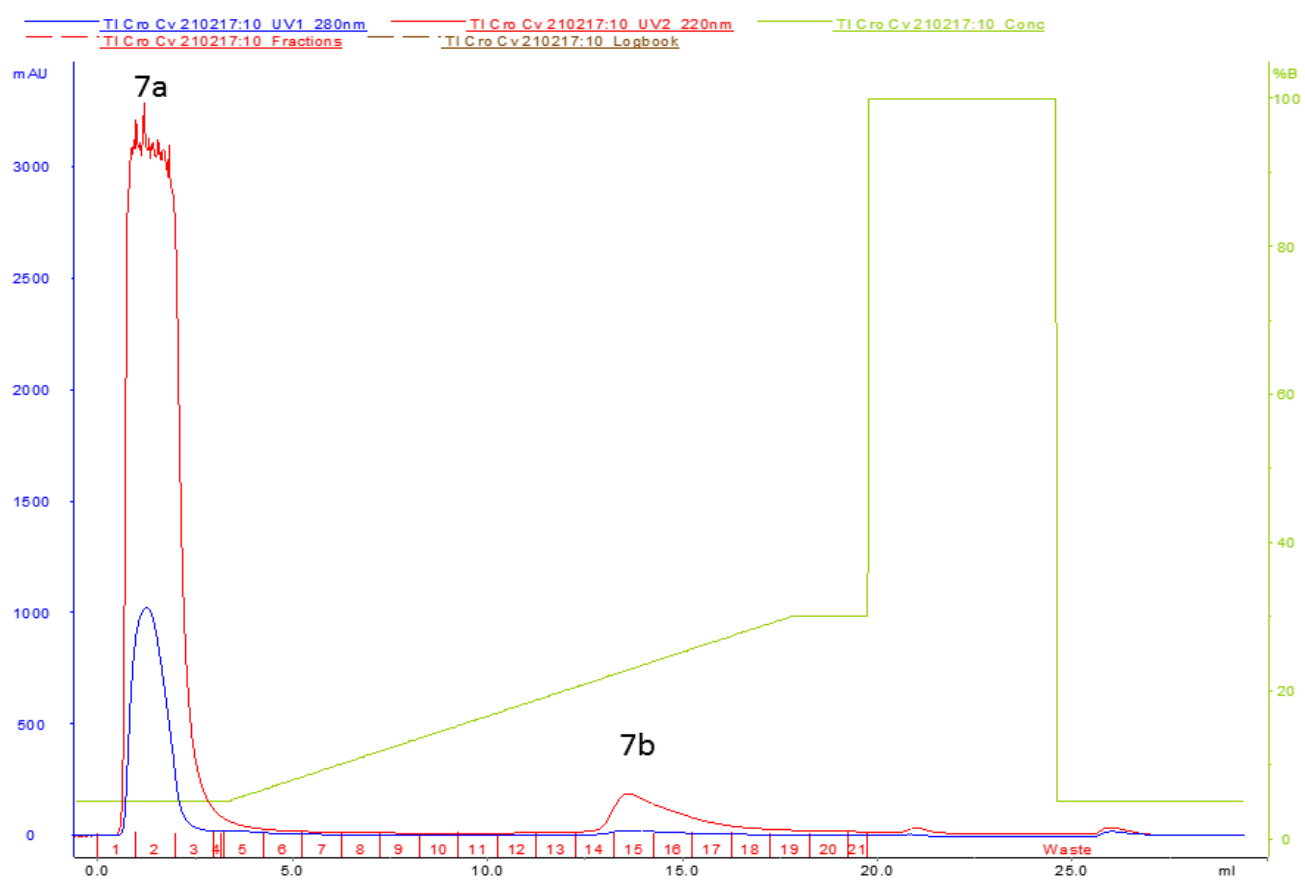

Fonte: A autora 
A metodologia utilizada foi eficiente, e, o gráfico obtido (figura 17) mostra que a fração não adsorvida, considerada contaminante, estava em maior quantidade quando comparada a fração adsorvida a resina, que foi eluída com gradiente salino. Ao passo que, quando comparamos a fração crotamina da $C$. d. t. (figura 8), o inverso é observado, há maior intensidade de absorbância na fração eluída com gradiante salino, do que a fração não adsorvida à resina.

Figura 18: SDS-PAGE a 15\%. M: padrão de massa molecular e $7 \mathrm{~b}$ : fração retida na cromatografia de troca catiônica

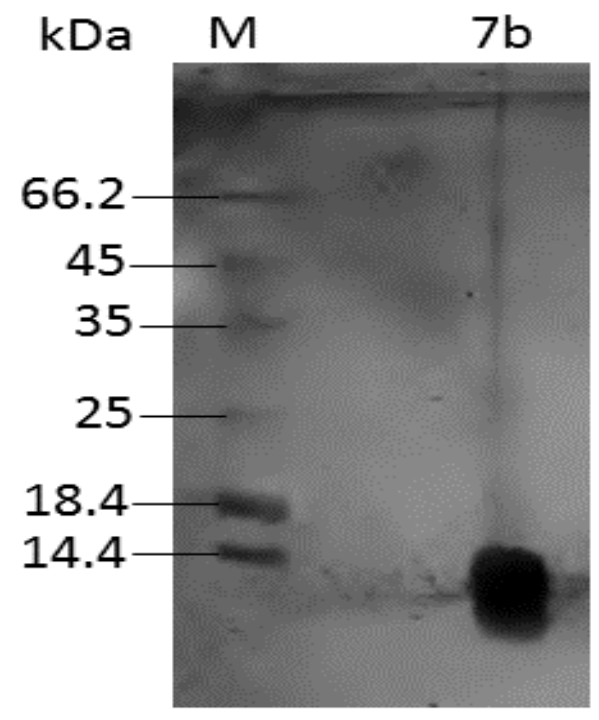

Fonte: A autora

Ao realizar o SDS-PAGE para confirmar a eficiência da técnica, observou-se uma banda correspondente única, com baixa massa molecular. $O$ que reforça a hipótese de ser uma molécula crotamina-símile.

\subsection{Antibiograma dos picos da exclusão molecular do veneno de $C$. $v$. testado em M. luteus.}

A figura 19 representa a propriedade antimicrobiana das frações do veneno de C.v. em diversas concentrações. Os controles C- e C+ (Anti), estão representados em todas as placas da mesma maneira. Na figura 19A, onde 0 pico 6 da cromatografia de exclusão molecular foi testado, mostra que não houve susceptibilidade dentre as diversas concentrações, partindo de 10 $\mathrm{mg} / \mathrm{mL}(1: 1)$ até $0,62 \mathrm{mg} / \mathrm{mL}(1: 16)$. 
Somente a partir da fração 7 (figura 19B), foi observada formação de halos que revelam a atividade antimicrobiana em todas as diluições feitas, confirmando a atividade antimicrobiana da fração de crotamina-símile.

Figura 19: Técnica de difusão em gota, com a bactéria $M$. luteus em ágar LB, testando as frações do veneno de C.v. Figura A: Fração 6 em diferentes concentrações; B: Fração 7 em diferentes concentrações; C: Fração 8 em diferentes concentrações; D: Fração 9 em diferentes concentrações.
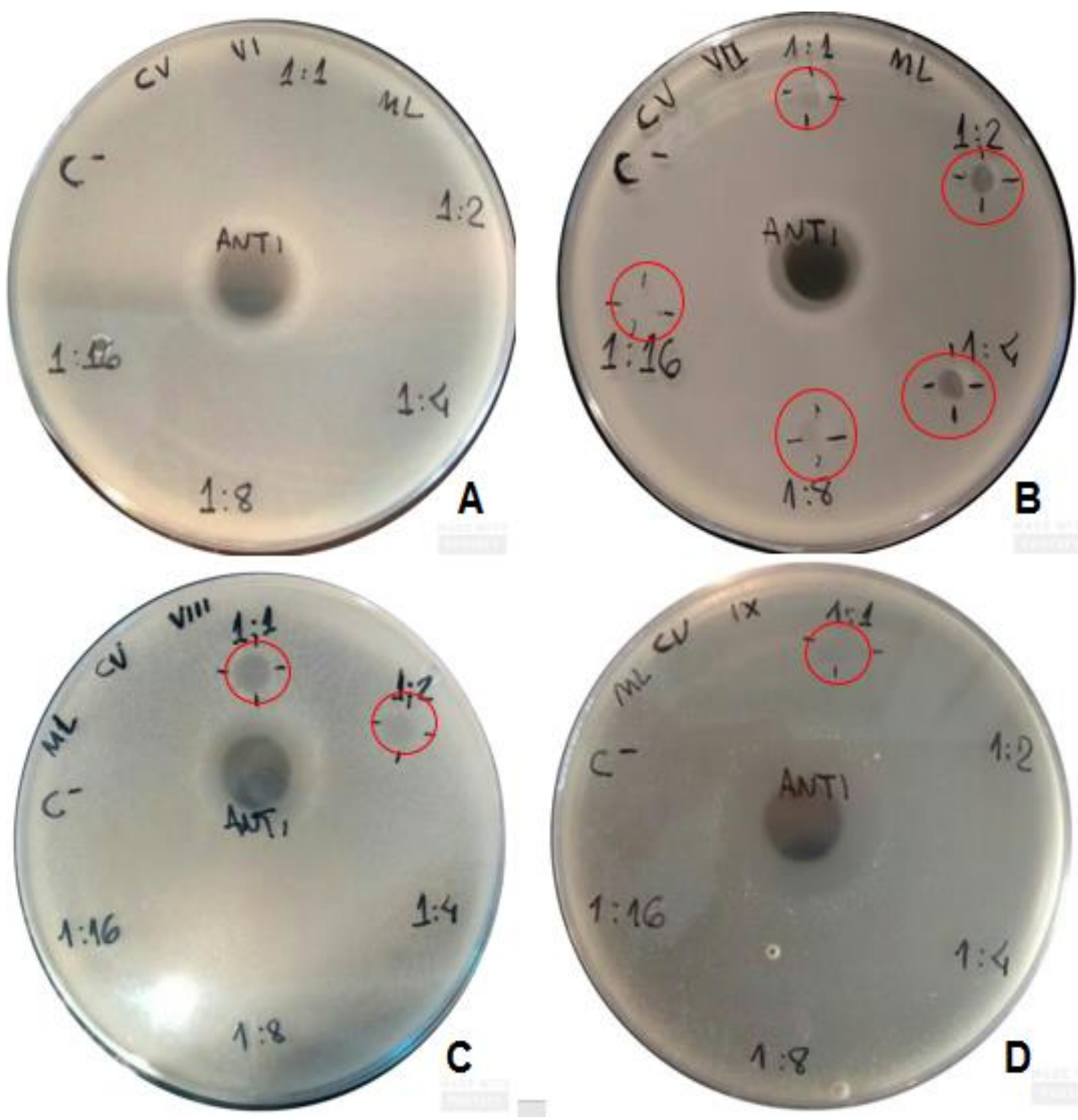

Fonte: A autora

A figura 19C, representada pela atividade antimicrobiana da fração 8 da exclusão molecular, somente apresentou halo de inibição nas diluições de 1:1 (10 mg/mL) e 1:2 (5 mg/mL). A fração 9 que também foi testada e encontra-se 
ilustrada na figura 19D, somente apresentou halo de inibição na diluição de 1:1 (10 mg/mL).

Sendo M. luteus a bactéria mais sensível a crotamina (CORREA, 2013), é esperado que as frações peptídicas 6, 7, 8 e 9 mostrem-se ativas. Porém, não houve halo de inibição para a fração 6 , possivelmente pela baixa concentração em que a amostra se encontrava.

Em comparação ao halo de inibição formado em $M$. luteus frente a crotamina de C.d.t., na figura 19, vemos halos bem delimitados, porém com diâmetros menores que na figura 10D. Porém, ao compararmos com as demais espécies, principalmente as Gram -, vemos que os halos estão com diâmetros próximos, com atividades semelhantes.

\subsection{Análise da fração crotamina de Crotalus durissus ruruima}

\subsubsection{SDS-PAGE $15 \%$ com fração crotamina de C.d.r.}

Visando a comprovação da existência do peptídeo isolado, foi realizada uma eletroforese, onde foi possível visualizar a fração crotamina-símile isolada.

Figura 20: SDS-PAGE a 15\%, onde M: padrão de massa molecular; C Cdt: crotamina de Cdt; C Cdr: crotamina de C. d. ruruima.

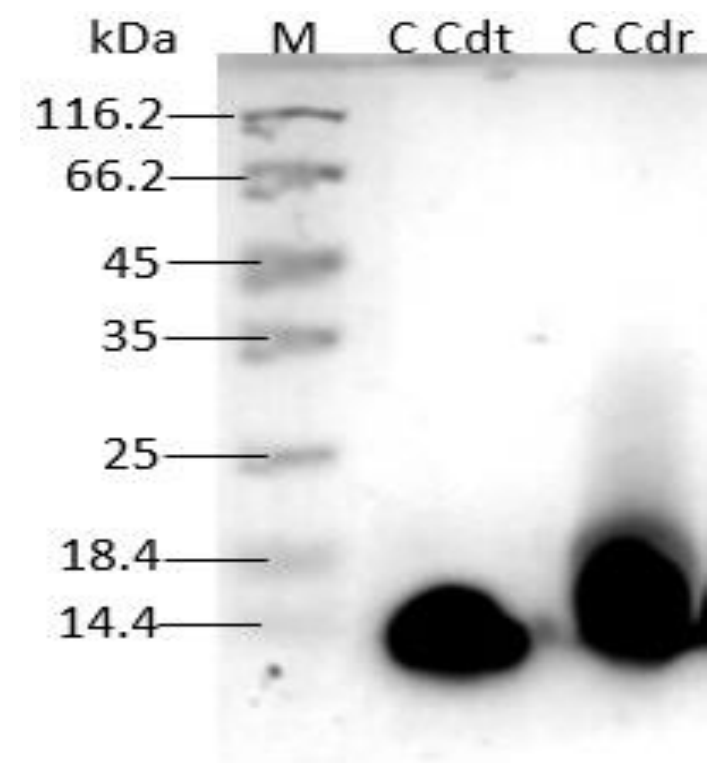


A figura 20 representa a crotamina e crotamina-símile (C.d.r.), em duas bandas que atestam a pureza da fração, validando o uso da fração para os ensaios posteriores.

\subsection{Análise comparativa da Concentração inibitória mínima (CIM) da crotamina e crotaminas-símile.}

O CIM foi realizado para acompanhamos a atividade antimicrobiana entre os três peptídeos estudados (crotamina, fração 6 de C.v. e crotaminasímile C.d.r.) utilizando 3 espécies bacterianas distintas.

Este ensaio foi importante para quantificarmos a atividade antimicrobiana em uma determinada concentração dos peptídeos testados em questão.

Figura 21: CIM realizado com crotamina em diferentes concentrações, onde $C+$ representa 0 antibiótico e C- somente células e meio de cultura.

E.coli

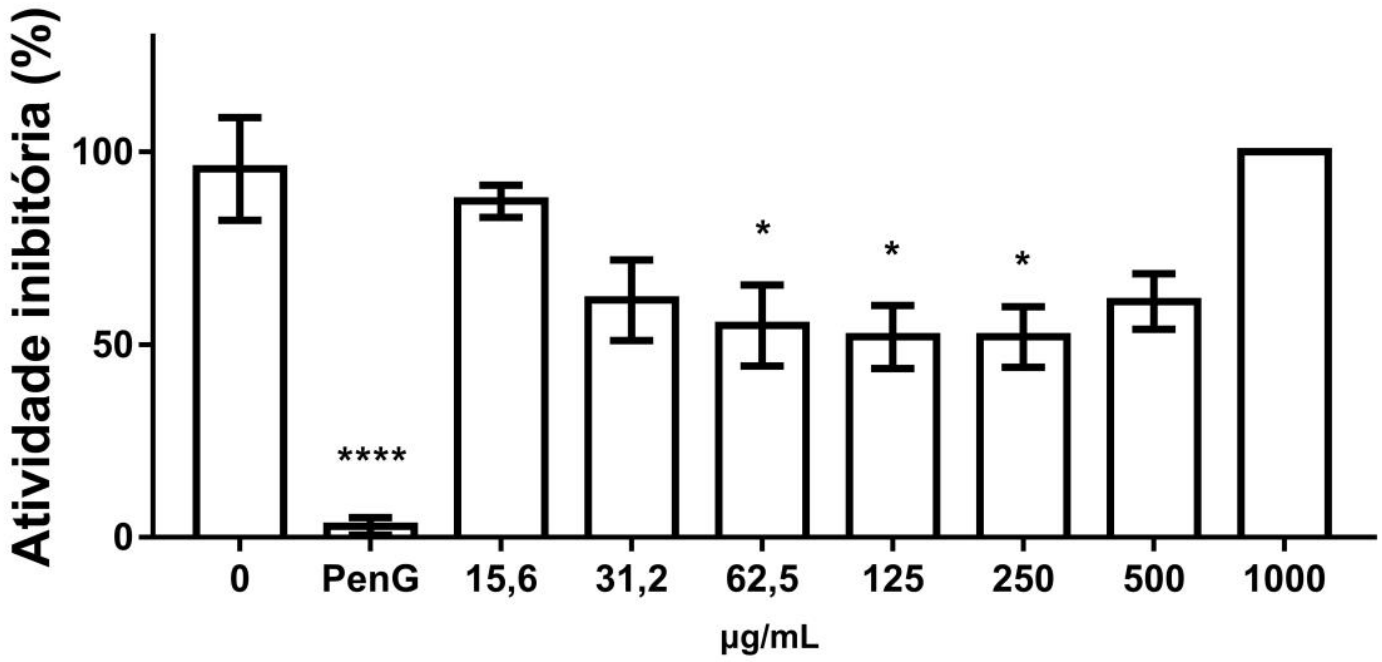

Fonte: A autora

A atividade antimicrobiana da crotamina em E. coli (figura 21), foi superior quando observamos a atividade inibitória em M. luteus (figura 22), dado este, que divergiu da literatura, que mostrou que a $M$. luteus é mais sensível que $E$. coli, quando é testada em crotamina nativa. Sendo que, em $E$. coli, o CIM foi de $100 \mu \mathrm{g} / \mathrm{mL}$, o mesmo encontrado por OGUIURA (2011). 
Figura 22: CIM realizado com crotamina em diferentes concentrações, testadas em M. luteus. Onde $\mathrm{C}+$ representa o antibiótico e C-, as bactérias com meio de cultura.

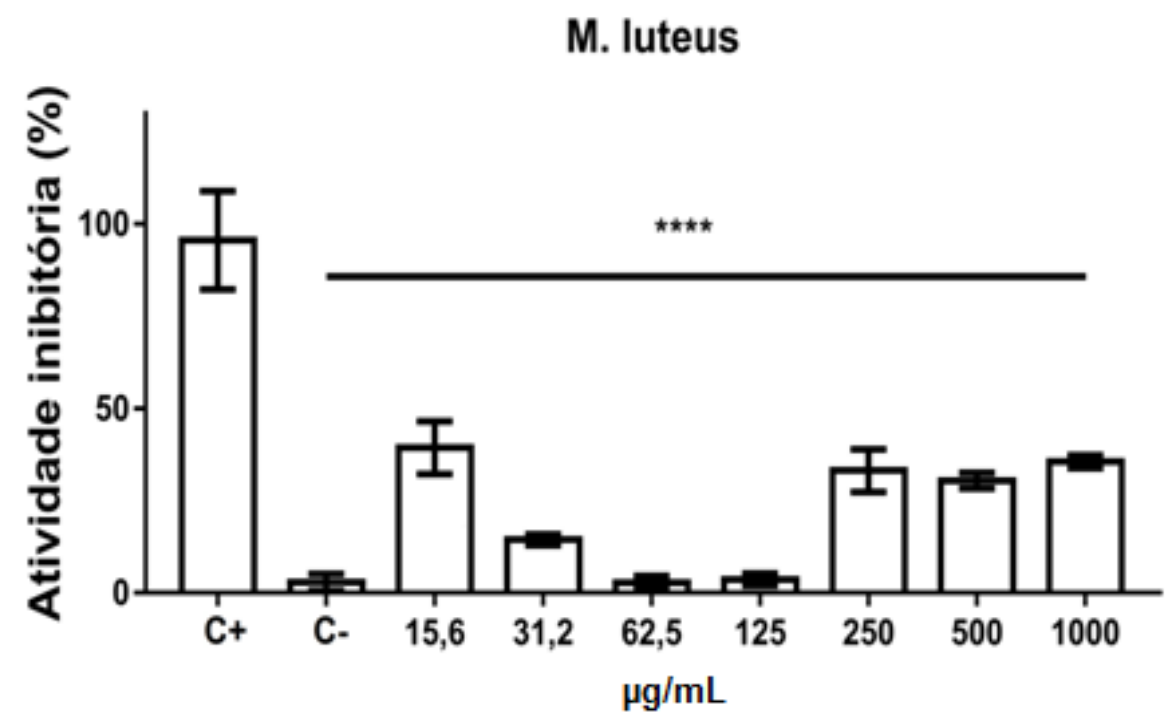

Fonte: A autora

Em M. luteus houve apenas a inibição parcial da espécie, mostrando que o CIM seria > $100 \mu \mathrm{g}$, fato que divergiu dos encontrados por CORREA (2013), que encontrou CIM desta espécie na concentração de $8 \mu \mathrm{g}$. Estas espécies são frequentemente utilizadas em ensaios antimicrobianos, pois tendem a ser mais susceptíveis aos fármacos testados (YAMANE et al., 2013).

Quando comparamos a atividade antimicrobiana da crotamina (figura 21 e 22) com a fração 6 de C.v. (figura 23), vemos que em M. luteus as atividades estão semelhantes, mostrando que somente na maior concentração há uma diferença substancial. 
Figura 23: CIM realizado com a fração 6 de C.v. em S. aureus, E. coli e M. luteus. Onde $\left.{ }^{*}\right) \mathrm{p}=$ 0,$\left.02 ;{ }^{* *}\right) p=0,001 ;\left(^{* * *}\right) p<0,0001$. Análise estatística por 2 way ANOVA, programa Graphpad Prism.

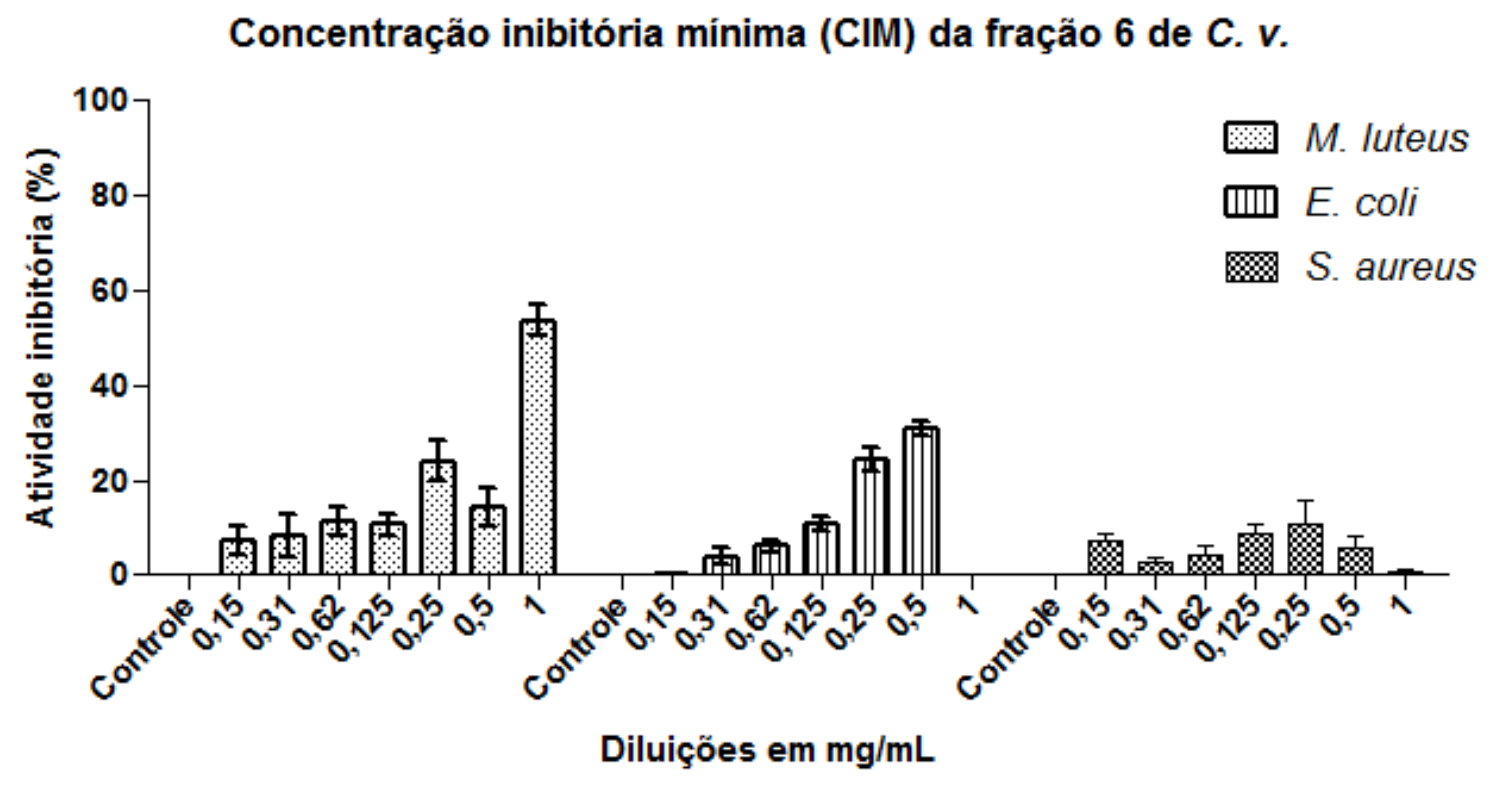

Fonte: A autora

Na técnica de difusão em gota, não foi possível detectar a atividade antimicrobiana da fração 6 de C.v. (figura 19A), porém, na técnica CIM, podemos observar na figura 22, uma atividade inibitória maior que $50 \%$ em $M$. luteus $(100 \mu \mathrm{g})$. Nas demais espécies, em diversas concentrações, a atividade inibitória não passou de 30\%, considerando inibição parcial.

A figura 23 mostra que a atividade inibitória foi parcial, e que somente para M. luteus a concentração inibitória de $100 \mu \mathrm{g}$ parece promissora. O ensaio de CIM confirma os dados obtidos por YAMANE et al, 2013, quando os mesmos testaram crotamina de C.d.t. Os asteriscos indicados na figura representam diferença estatística frente ao controle. 
Figura 24: CIM realizado com a fração crotamina-símile de C.d.r. em S. aureus, E. coli e $M$. luteus. Onde $\left(^{* *}\right) p=0,002$ e $\left(^{* * *}\right) p<0,0001$. Análise estatística por 2 way ANOVA, programa Graphpad Prism.

\section{Concentração inibitória mínima (CIM) da fração crotamina-símile de C.d.r.}

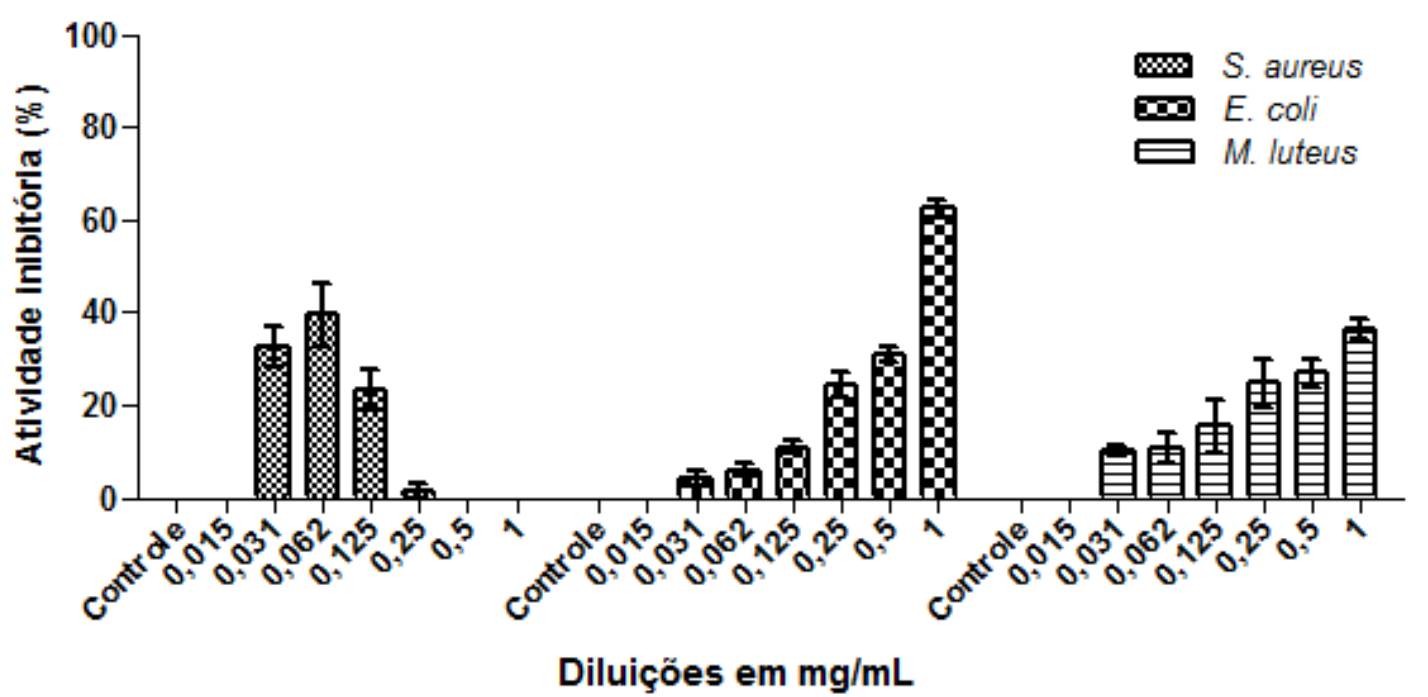

Fonte: A autora

$\mathrm{Na}$ figura 24, podemos observar que a maior atividade antimicrobiana da fração crotamina-símile de C.d.r. está na maior concentração frente a bactéria E. coli, onde a atividade inibitória chega a $62 \%$, porém o CIM seria $>1 \mathrm{mg} / \mathrm{mL}$. Quando testada frente a $S$. aureus, a fração oriunda de C.d.r. apresentou atividade nas concentrações mais baixas, enquanto as concentrações mais altas mostraram menor atividade inibitória. Nas diferentes concentrações de peptídeo, vemos que nas diferentes espécies, exceto $E$. coli a atividade inibitória não foi maior que $40 \%$. Os pontos indicados com asterisco representam diferença estatística frente ao controle.

Os dados obtidos da fração crotamina-símile de C.d.r., assemelham-se aos dados descritos por OGUIURA e colaboradores, 2011, quando os autores descrevem que a $E$. coli pode chegar a ter um CIM de $100 \mu \mathrm{g} / \mathrm{mL}$ em crotamina nativa.

Fazendo uma análise comparativa podemos inferir que a crotamina (C.d.t.) tem maior atividade antimicrobiana em E. coli. Ao analisar o teste feito em $M$. luteus, foi observado que a maior inibição parcial foi encontrada na concentração de $100 \mu \mathrm{g} / \mathrm{mL}$, em todos os peptídeos testados, porém a maior porcentagem de inibição está na fração 6 C.v.. E por fim, ao analisarmos a 
bactéria $S$. aureus, a melhor inibição parcial encontrada foi em crotamina-símile de C.d.r.

Compreendendo assim, que o todos os CIM, foram maiores ou iguais a $100 \mu g$.

\subsection{Citotoxicidade em células 3T3}

A citotoxicidade foi avaliada para garantir que as frações testadas não possuam toxicidade frente a células de mamífero.

Figura 25: Ensaio de citotoxicidade, realizado com as frações de Crotamina (C.d.t.) e crotamina símile de C.v. e C.d.r. Onde $\left({ }^{*}\right) p<0,05 ;\left({ }^{* *}\right) p=0,0003 ;\left({ }^{* *}\right) p=0,0004 ;\left({ }^{* * *}\right) p<0,0001$. Análise estatística 2way ANOVA, programa Graphpad Prism.

\section{Citotoxicidade por MTS em células 3T3}

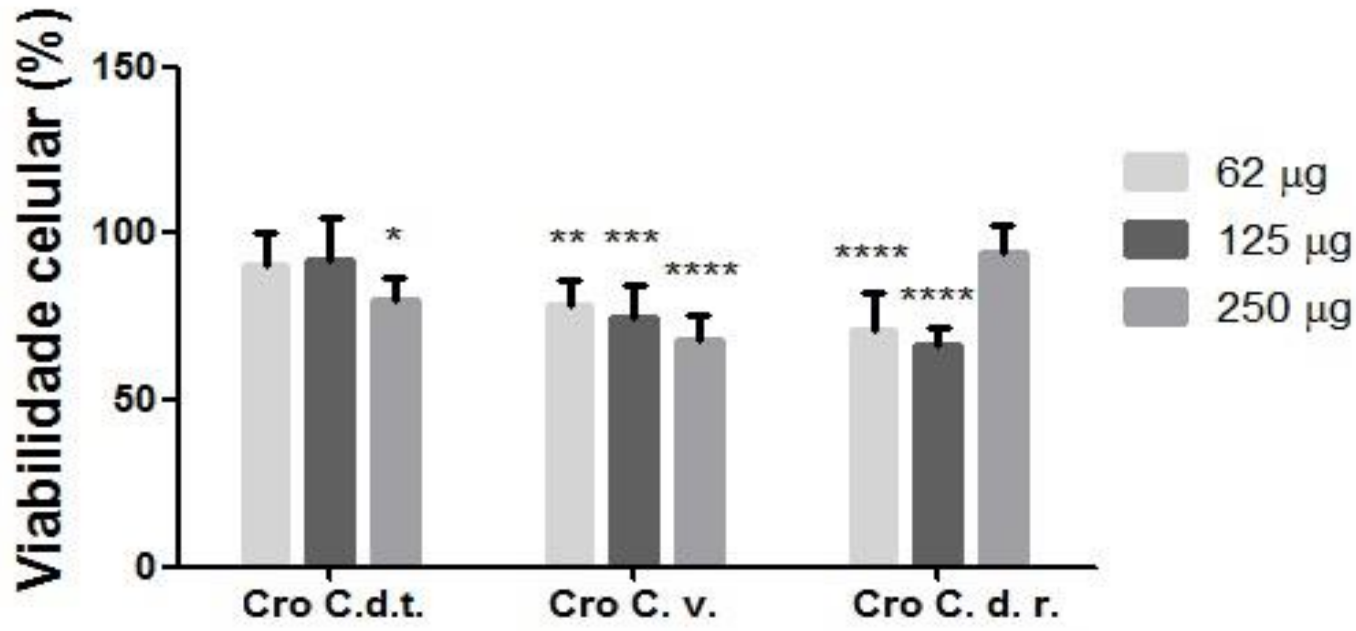

Fonte: A autora

Os dados de viabilidade celular (figura 25) mostram que em nenhuma das concentrações testadas, houve viabilidade inferior a 65\%. Este fato sugere que as frações crotamina e crotaminas-símile apresentam pouca ou nenhuma toxicidade de acordo com as frações testadas.

A crotamina isolada, não apresentou toxicidade em experimentos in vitro. Esta propriedade não-tóxica já foi observada em eritrócitos por OGUIURA e colaboradores, (2011), em células 3T3 por PEREIRA, (2011) e não foi constatado alta toxicidade da crotamina isolada em nenhum dos trabalhos. 


\section{CONCLUSÃO}

$\checkmark$ Todas os venenos e peptídeos testados foram imunorreativos frente ao anticorpo anti-crotamina

$\checkmark$ O protocolo de purificação utilizado foi eficiente

$\checkmark$ As frações C. d. t. e C. d. r. testadas tinham elevado grau de pureza, de acordo com o SDS-PAGE

$\checkmark$ Sugere-se que o sítio para atividade antimicrobiana esteja mais exposto e susceptível ao compararmos com o sítio para atividade miotóxica, que aparenta ser mais preservado na molécula

$\checkmark$ Todos os peptídeos e frações testadas demonstraram atividade antimicrobiana em especificidades e potências diferentes

$\checkmark$ Nenhum peptídeo ou fração demonstrou citotoxicidade frente a fibroblastos murinos

$\checkmark$ Sendo assim, as moléculas testadas têm potencial como protofármaco. 


\section{REFERÊNCIAS}

BAUER, A. W. et al. Antibiotic susceptibility testing by a standardized single disk method. American journal of clinical pathology, v. 45, n. 4, p. 493, 1966.

BENKO-ISEPPON, Ana Maria et al. Overview on plant antimicrobial peptides. Current Protein and Peptide Science, v. 11, n. 3, p. 181-188, 2010.

BOBER, Mary A. et al. Detection of myotoxin a-like proteins in various snake venoms. Toxicon, v. 26, n. 7, p. 665-673, 1988.

BON, C. Snake venom \& pharmacopeia. Snakes: a natural history. Sterling Publishing Company, Inc., New York, v.1, p. 194-203, 1994.

C BELARMINO, Luis; M BENKO-ISEPPON, Ana. Data bank based mining on the track of antimicrobial weapons in plant genomes. Current Protein and Peptide Science, v. 11, n. 3, p. 195-198, 2010.

CARDOSO, J. L. C., et al. Animais peçonhentos no Brasil: biologia, clínica e terapêutica dos acidentes. São Paulo: Sarvier, 2003. Pp. 160-172, 299-300, 445-446, 456-457.

CARREIRA, O.C.A., et al. Biofármacos: sua importância e as técnicas utilizadas em sua produção. Rev. Genética na Escola, v. 08, p. 2, 2013

CORONADO, MONIKA M.A. et al. Structure of the polypeptide crotamine from the Brazilian rattlesnake Crotalus durissus terrificus. Acta Crystallographica Section D: Biological Crystallography, v. 69, n. 10, p. 1958-1964, 2013.

CORREA, P.G., OGUIURA, N. Phylogenetic analysis of $\beta$-defensin-like genes of Bothrops, Crotalus and Lachesis snakes. Toxicon, v. 69, p. 65-74, 2013.

COSTA, Bruno B. A. et al. Interaction of the rattlesnake toxin crotamine with model membranes. The Journal of Physical Chemistry B, v. 118, n. 20, p. 5471-5479, 2014.

CRUZEIRO-SILVA, C. et al. Structural biology of membrane-acting peptides: conformational plasticity of anticoccidial peptide PW2 probed by solution NMR. Biochimica et biophysica acta, v. 1768, n. 12, p. 3182-92, 2007.

CUNHA, B.A. Antibiotic resistance. Drugs of Today, v. 34, p. 691-698, 1998.

DAL MAS, C. et al. Anthelmintic effects of a cationic toxin from a South American rattlesnake venom. Toxicon, v. 116, p. 49-55, 2016.

DE SOUZA SPINOSA, Helenice; GORNIAK, Silvana Lima; NETO, João Palermo. Toxicologia apliacada à medicina veterinária. Manole, 2008.

DONATO, Micheline M.F.Freire et al. Purificação, caracterização bioquímica e eletrofisiológica da toxina Mic6c7NTX da Peçonha da Serpente Micrurus ibiboboca (Merrem, 1820). 2008. 
DOS SANTOS, M.aria Cristina C. et al. Caracterización de las actividades biológicas de los venenos 'amarillo'y 'blanco'de Crotalus durissus ruruima comparados con el veneno de Crotalus durissus terrificus. Poder neutralizante de los antivenenos frente a los venenos de Crotalus durissus ruruima. Toxicon, v. 31, n. 11, p. 1459-1469, 1993.

DOS SANTOS, M.C. dos et al. Purification and properties of a crotamine analog from Crotalus durissus ruruima venom. Toxicon, v. 31, p. 166, 1993.

DU, XIAO-YAN; CLEMETSON, Kenneth J. Snake venom L-amino acid oxidases. Toxicon, v. 40, n. 6, p. 659-665, 2002.

E SILVA, M. Rocha; BERALDO, Wilson T.; ROSENFELD, G. Bradykinin, a hypotensive and smooth muscle stimulating factor released from plasma globulin by snake venoms and by trypsin. American Journal of Physiology-Legacy Content, v. 156, n. 2, p. 261-273, 1949.

ENGVALL, Eva; PERLMANN, Peter. Enzyme-linked immunosorbent assay (ELISA) quantitative assay of immunoglobulin G. Immunochemistry, v. 8, n. 9, p. 871-874, 1971.

FAURE, Grazyna.; BON, Cassian.. Crotoxin, a phospholipase A2 neurotoxin from the South American rattlesnake Crotalus durissus terrificus: purification of several isoforms and comparison of their molecular structure and of their biological activities. Biochemistry, v. 27, n. 2, p. 730-738, 1988.

GIRALT, E. et al. Design, synthesis and structure of peptides and proteins.IRB Barcelona (Institute for Research in Biomedicine) Annual Report 2005-2006. Chemistry and Molecular Pharmacology Programme.

GOLÇALVES, J.M, ARANTES, E.G. Estudos sobre venenos de serpentes brasileiras III - Determinação quantitativa de crotamina no veneno de cascavel Brasileira. An. Acad. Brás. Cienc., v. 22, p. 141-50, 1956.

HANCOCK, R. E. W.; SAHL, H.-G. Antimicrobial and host-defense peptides as new antiinfective therapeutic strategies. Nature biotechnology, v. 24, n. 12, p. 1551-7, 2006.

HAWKEY, Peter $M$. The origins and molecular basis of antibiotic resistance. BMJ: British Medical Journal, v. 317, n. 7159, p. 657, 1998.

HERNANDEZ-OLIVEIRA, Saraguaci. et al. Biochemical, pharmacological and structural characterization of a new PLA 2 from Crotalus durissus terrificus (South American rattlesnake) venom. The protein journal, v. 24, n. 4, p. 233242, 2005.

HOLMES, Alison A.H. et al. Understanding the mechanisms and drivers of antimicrobial resistance. The Lancet, v. 387, n. 10014, p. 176-187, 2016.

JACOBY, G.A. Epidemiology of extended-spectrum b-lactamases. Clinical Infectious Diseases, v. 27, p. 81-83, 1998. 
JACOBY, G. A., ARCHER, G.L. New mechanisms of bacterial resistance to antimicrobial agents. New England Journal of Medicine, v. 324, p. 601-612, 1991.

LAEMMLMLI, U.K., BEGUIN, F., GUJER-KELLENBERGER, G. A factor preventing the major head protein of bacteriophage $\mathrm{T} 4$ from random aggregation. J Mol Biol, v. 14; n. 47, p. 69-85, 1970.

LAURE, C.J. The primary structure of crotamine. Hoppe Seylers Z Physiol Chem, v.356, p. 213-5, 1975.

LEVY, Stuart S.B. Balancing the drug-resistance equation. Trends in microbiology, v. 2, n. 10, p. 341-342, 1994.

LEWIS, R.J.; GARCIA, M.L., Therapeutic potential of venom peptides. Nature Review a Drug Discovery, v. 2, p. 790-802, 2003.

MALANOVIC, Nermina; LOHNER, Karl. Antimicrobial Peptides Targeting GramPositive Bacteria. Pharmaceuticals, v. 9, n. 3, p. 59, 2016.

MALUF, S. El Chamy et al. Inhibition of malaria parasite Plasmodium falciparum development by crotamine, a cell penetrating peptide from the snake venom. Peptides, v. 78, p. 11-16, 2016.

MANCIN, A. C., SOARES, A. M., ANDRIAO--ESCARSO, S. H., FACA, V. M., GREENE, L. J., ZUCCOLOTTO, S., PELA, I.R.; GIGLIO, J.R. The analgesic activity of crotamine, a neurotoxin from Crotalus durissus terrificus (South American rattlesnake) venom: a biochemical and pharmacological study. Toxicon, v. 36, n. 2, p. 1927-1937, 1998.

MANCIN, A.C.; SOARES, A.M.; GIGLIO, C.A.; ANDRIAO-ESCARSO, S.H.; VIEIRA, C.A.; GIGLIO, J.R. The histamine releasers crotamine, protamine and compound $48 / 80$ activate specific proteases and phospholipases A2. Biochem Mol Biollnt., v. 42, n. 6, p. 1171-7, 1997.

MARTÍNEZ, J.L., COQUE, T.M., BAQUERO, F. What is a resistance gene? Ranking risk in resistomes. Nat Rev Microbiol, v. 13, n. 2, p. 116-23, 2015.

MICHAEL, C.arolyn A.nne; DOMINEY-HOWES, D.ale; LABBATE, M.aurizio. The antimicrobial resistance crisis: causes, consequences, and management. Frontiers in public health, v. 2, p. 145, 2014.

MOORE, Sara WM et al. Isolation and characterisation of insulin-releasing compounds from Crotalus adamanteus, Crotalus vegrandis and Bitis nasicornis venom. Toxicon, v. 101, p. 48-54, 2015.

NICASTRO, G., FRANZONI, L.. CHIARA, C., MANCIN, A. C., GIGLIO, J. R. \& SPISNI, A. (2003). Solution structure of crotamine, a Na+ channel affecting toxin from Crotalus durissus terrificus venom. Eur J Biochem, v. 270, n. 9, p. 1969-1979, 2003.

ODINTSOVA, T.; EGOROV, T. Plant Antimicrobial Peptides. In: H. R. Irving; C. Gehring (Eds.); Plant Signaling Peptides. v. 16, p.107-133, 2012. Berlin, Heidelberg: Springer Berlin Heidelberg. 
OGUIURA, Nancy et al. In vitro antibacterial and hemolytic activities of crotamine, a small basic myotoxin from rattlesnake Crotalus durissus. The Journal of antibiotics, v. 64, n. 4, p. 327-331, 2011.

OGUIURA, N.; BONI-MITAKE, M.; RÁDIS-BAPTISTA, G. New view on crotamine, a small basic polypeptide myotoxin from South American rattlesnake venom. Toxicon, v. 46, n. 4, p. 363-370, 2005.

OLIVEIRA, Karina Corleto et al. New insights into the structural characteristics of irradiated crotamine. Journal of Venomous Animals and Toxins including Tropical Diseases, v. 21, n. 1, p. 14, 2015.

OWNBY, Charlotte L.; AIRD, Steven D.; KAISER, Ivan I. Physiological and immunological properties of small myotoxins from the venom of the midget faded rattlesnake (Crotalus viridis concolor). Toxicon, v. 26, n. 3, p. 319-323, 1988.

PEREIRA, Alexandre, et al. Crotamine toxicity and efficacy in mouse models of melanoma. Expert opinion on investigational drugs, v. 20, n. 9, p. 11891200, 2011.

PESCHEL, A.; SAHL, H.-G. The co-evolution of host cationic antimicrobial peptides and microbial resistance. Nature reviews. Microbiology, v. 4, n. 7, p. 529-36, 2006.

PINHO, F. M. O. \& PEREIRA, I. D., Ofidismo. Rev. Ass. Med. Brasil., v. 27, n. 1, p. 24, 2001.

PONCE-SOTO, Luis Alberto et al. Structural and biological characterization of two crotamine isoforms IV-2 and IV-3 isolated from the Crotalus durissus cumanensis venom. The protein journal, v. 26, n. 8, p. 533-540, 2007.

QUEIROZ, S. J. Identificação da Atividade Antimicrobiana no Veneno da Serpente Bothrops moojeni em Bactérias Gram Negativas. Mestrado em Ciências Ambientais e Saúde, PUC. Goiânia, GO. 2010.

RANGEL-SANTOS, A.; DOS-SANTOS, E. C.; LOPES-FERREIRA, M.; LIMA, C.; CARDOSO, D. F.; MOTA, I., A comparative study of biological activities of crotoxina and $\mathrm{CB}$ fraction of venoms from Crotalus durissus terrificus, Crotalus durissus cascavella and Crotalus durissus collilineatus. Toxicon., v.43, n.7, p. 801-810, 2004.

RODRIGUEZ-ACOSTA, A.R., MANDOLFI, A., ORIHUELA, R., Qué hacer frente a um accidente ofídico? Caracas: Venediciones, v. 1, p. 23-9, 1995.

SALYERS, Abigail A.; AMABILE-CUEVAS, Carlos F. Why are antibiotic resistance genes so resistant to elimination?. Antimicrobial agents and chemotherapy, v. 41, n. 11, p. 2321, 1997.

SAMBROOK, Joseph et al. Molecular cloning: a laboratory manual. Cold spring harbor laboratory press, 1989. 
SATO, H.; FEIX, J. B. Peptide-membrane interactions and mechanisms of membrane destruction by amphipathic alpha-helical antimicrobial peptides. Biochimica et biophysica acta, v. 1758, n. 9, p. 1245- 56, 2006.

SIEBER, M., BOSCH, B., HANKE, W., FERNANDES DE LIMA, V.M. Membrane-modifying properties of crotamine, a small peptide-toxin from Crotalus durissus terifficus venom. Biochim Biophys Acta, v. 1840, n. 3, p. 945-50, 2014.

STOCKER, Kurt. Snake venom proteins affecting hemostasis and fibrinolysis. Medical use of snake venom proteins, p.97-160, 1990.

TOKE, Orsolya. Antimicrobial peptides: new candidates in the fight against bacterial infections. Peptide Science, v. 80, n. 6, p 717-735, 2005.

TORRES, Allan M.; KUCHEL, Phillip W. The $\beta$-defensin-fold family of polypeptides. Toxicon, v. 44, n. 6, p. 581-588, 2004

TOYAMA, Daniela Oliveira et al. Structure-function relationship of new crotamine isoform from the Crotalus durissus cascavella. The protein journal, v. 24, n. 1, p. 9-19, 2005.

VIALA, Vincent Louis et al. Proteomic analysis of the rare Uracoan rattlesnake Crotalus vegrandis venom: evidence of a broad arsenal of toxins. Toxicon, $v$. 107, p. 234-251, 2015.

VIEIRA, A. C. Ação de vários agentes sobre o efeito paralisante dos membros posteriores induzido pela crotamina e camundongos. Biosci. J. Uberlândia. 2006, 22:125-32.

$\mathrm{XIAO}$, Yanjing et al. Identification and functional characterization of three chicken cathelicidins with potent antimicrobial activity. Journal of Biological Chemistry, v. 281, n. 5, p. 2858-2867, 2006.

YAMANE, Erica $S$. et al. Unraveling the antifungal activity of a South American rattlesnake toxin crotamine. Biochimie, v. 95, n. 2, p. 231-240, 2013.

YOUNT, Nannette $Y$. et al. Selective reciprocity in antimicrobial activity versus citotoxicity of hDB-2 and crotamine. Proceedings of the National Academy of Sciences, v. 106, n. 35, p. 14972-14977, 2009. 


\section{INSTITUTO DE PESQUISAS ENERGÉTICAS E NUCLEARES}

Diretoria de Pesquisa, Desenvolvimento e Ensino

Av. Prof. Lineu Prestes, 2242 - Cidade Universitária CEP: 05508-000

Fone/Fax(0XX11) 3133-8908

SÃO PAULO - São Paulo - Brasil

http://www.ipen.br

O IPEN é uma Autaquia vinculada à Secretaria de Desenvolvimento, associada à Universiade de São Paulo e gerida técnica e administrativamente pela Comissão Nacional de Energia Nuclear, órgão do Ministério da Ciência, Tecnologia e Inovação. 